\title{
A HISTORY OF AFRO-AMERICANS \\ IN NEW JERSEY
}

\author{
BYL.A. GREENE
}

Professor Greene is Chairman of the History Department at Seton Hall University

\section{Preface}

Far too many residents of New Jersey believe the present conditions of race relations and the status of Afro-Americans characterize not only the contemporary era but also the past. Today, a number of New Jersey municipalities have black mayors and representatives in the state legislature, but less well known is the disenfranchisement of blacks in the preCivil War era. Today, despite a significant gap between black and white incomes, blacks are employed as unskilled laborers, in skilled jobs, and as professionals. Yet in the seventeenth and eighteenth centuries, most New Jersey Afro-Americans were in the bondage of slavery. July 4, 1776, stimulates memories of Patrick Henry, Thomas Jefferson, George Washington, and other heroes of the American Revolution, but few have heard of Prince Whipple or Jack Cudjo, black Jerseyans who served the patriot military cause during the Revolution. Nor has July 4, 1804, the date New Jersey's gradual abolition of slavery law took effect, been imprinted in the collective memory of the state's citizens. If our knowledge of the history of Afro-Americans in New Jersey contains such omissions, it is my hope that this work will generate new knowledge and interest in this too-often ignored or only faintly understood topic.

This study covers in six sections the Afro-American experience in the state from the colonial period to the present. The first section will focus on the origins and growth of African slavery. The similarities to and differences from slavery on southern plantations are explored. The second section examines the contributions of blacks to the Revolutionary War effort and the impact of the natural rights philosophy of the Revolution, economic factors, and Quaker antislavery efforts on the state legislature's passage of a gradual abolition law. The third section explores the ambiguous legal status of New Jersey's free black population between 1816 and 1865. Of particular concern are the racial attitudes, feelings pro and anti slavery, and loyalties during the Civil War in a state noted for its lukewarm support of the Union and Lincoln. The fourth section examines the period from the end of the Civil War to the turn of the century: the establishment of black 
businesses, churches, newspapers, and other institutions maintaining black culture. The fifth section studies the beginning of the twentieth century to the end of World War II, when the black population grew rapidly from southern migration to New Jersey's major cities as black southerners sought a better life. Their experience in those cities, hardships from massive unemployment in the Great Depression, and contributions to the American victory during both World Wars testify to the resiliency of New Jersey's black population. The final section covers the period from 1945 to the present, analyzing those social, economic, and political factors responsible for the shape of the Afro-American community today. It sets forth a retrospective view and discusses future prospects.

\section{The Origins and Growth of Slavery}

New Jersey's fertile soil, rivers, and forests became host to Dutch, English, Swedish, and German immigrants joining the native LenniLenape Indians, but the labor needs of first the Dutch colony and later the English one were unsatisfied by these early settlers and native Americans. As European immigration continued into the colonies, the native populations fell victim to European diseases and enslavement. Other natives migrated westward while the remainder proved too limited a source of labor. White indentured servants were inadequate, for their terms of service were limited and they often ran away. Like other colonies throughout the Western Hemisphere, New Jersey turned to the importation and enslavement of Africans. Slavery is not generally associated with the North or New Jersey by most Americans or New Jerseyans, but it was an important part of the northern as well as the southern economy. New York and New Jersey were the largest slaveholding states in the North with slave populations of 8 and 12 percent respectively through the colonial era. ${ }^{1}$ As Edgar McManus noted: "For nearly two hundred years the North maintained a slave regime more varied and complex than the 'peculiar institutions' of the South." The northern slave labor force, unlike the primarily agricultural southern labor force, was used in virtually every area of northern economic life. Blacks were exploited not only on farms, but also as carpenters, shipwrights, sailmakers, printers, tailors, shoemakers, coopers, blacksmiths, bakers, weavers, and goldsmiths. New Jersey black bondsmen were a part of this diversified labor system, making profits not only for the transatlantic slave traders and shipbuilding industry, but also for virtually every sector of the economy. ${ }^{2}$

Black labor was employed in the Jersey area even before English colonization. As early as 1627 , the Dutch West India Company brought Africans into the New Netherland colony, which encompassed the Hudson and Delaware River valleys, from ships they raided importing Africans into Spanish possessions in the New World. The leaders of New Netherland deemed black labor essential to their agricultural prosperity and the defense against hostile Indians. With Holland prosperous, the colony of New 
Netherland found it difficult to attract a sufficiently permanent Dutch labor supply and increasingly relied on African labor to clear forests, build roads, construct homes, and produce food to make the colony viable. Along the Hudson Valley, where the land monopolies of wealthy Dutch estate owners discouraged free immigration, African labor was especially important. Dutch farmers had probably carried their slaves to the now New Jersey side of the Hudson before the coming of the English in 1664, although the earliest record of African slaves in New Jersey was made in Shrewsbury in $1680 .^{3}$

The English conquest of New Netherland in 1664 did not alter the region's increasing reliance on black labor. Legal recognition of slavery in the middle colonies began with the English occupation of the Dutch colony, for during the period of Dutch control, the enslavement of blacks had been based on custom and usage rather than on law. However, the Articles of Capitulation, which transferred sovereignty from the Dutch to the English, recognized Dutch slave titles. The following year a statute making slavery a legal institution was promulgated by James, Duke of York, to whom his brother, Charles II of England, had granted New Netherland. James conferred the colony on John, Lord Berkeley, and Sir George Carteret. Under their auspices New Jersey's first Constitution, the Concessions and Agreement, was issued in $1665 .^{4}$

Under the provisions of the Concessions, every freeman who accompanied Governor Philip Carteret on his first voyage to New Jersey in 1665 was promised a "headright" (land grant of 150 acres). Additional grants of 75, 60, 45 , and 30 acres in succeeding years were made to colonists for bringing in indentured servants and slaves. The acknowledgement of the inadequacy of white servitude and Indian slavery and the decision to rely heavily on African slavery were not unique, but rather demonstrated the similarity of New Jersey's thinking and action to those of other colonies. ${ }^{5}$ The Concessions gave legal recognition to slavery and encouraged settlement and economic development by stimulating the introduction of African slaves and white indentured labor.

The division of the colony in 1674 into the two separate political and territorial units of East Jersey and West Jersey signaled the divergent paths followed by these geographical areas regarding slavery and race relations in the colonial period. The counties of Bergen, Essex, Monmouth, and Middlesex, originally forming East Jersey, contained a black population which numbered between 10 and 12 percent of the population on the eve of the Revolution, and even 20 percent in some communities. In contrast, the West Jersey colonies of Burlington, Gloucester, Salem, and Cape May contained a black population of only $4 \frac{1}{2}$ percent of the total at the time of the Revolution. East Jersey's greater reliance on black labor was stimulated by its proximity to New York City with its relatively large slave population (20 percent by 1715), Kings County (Brooklyn), and the Hudson River 
Valley where large Dutch estates employed slave labor. Like the rich farmland of Kings County and the Hudson River Valley, the fertile river valleys of the Passaic and the Raritan encouraged the use of slave labor. East Jersey became a magnet for the ambitious residents of New Netherland and planters from Barbados. The Barbadian transplants were the first to receive huge grants of land in seventeenth-century New Jersey. Both groups used slave labor to fell trees and clear thousands of acres of wilderness. The New York Dutch who crossed the Hudson or sailed from Long Island to Monmouth County and the Raritan Valley established estates there in the townships of Middletown, Freehold, and Shrewsbury. One of the earliest records of African slavery in New Jersey comes from the estate of Colonel Lewis Morris, a Barbadian planter, who in the early 1680 s employed sixty to seventy blacks in his Shrewsbury manor. ${ }^{6}$

Slavery existed in West Jersey but on a far less extensive scale. A significant portion of the land in West Jersey-pine barrens and marshlands along stretches of the Delaware River-was unsuitable for farming. The absence of significant Dutch migration and Barbadian immigration into West Jersey meant that these two slaveholding groups had a very limited presence in the area. West Jersey's proximity to the port of Philadelphia, where white servants were abundant, and its distance from the more slavetrade-oriented port of New York contributed to the lower percentage of blacks and slaves in the area. Finally, the English Quakers in West Jersey supported the antislavery movement: evolving Quaker moral antipathy to slavery culminated in a 1776 decision to read slaveholders out of the Philadelphia and West Jersey meetings. Quakers had tried to lessen the burden of slavery and encourage slave emancipations throughout much of the eighteenth century and by the end of the century they sought to

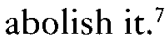

During the first half of the eighteenth century, thousands of blacks were brought into New York and New Jersey from Barbados and Jamaica. In 1726, blacks numbered 2,581 out of a total New Jersey population of 32,422. By 1745 , there were approximately 4,606 blacks in a population of 61,383 in the state. The growing black population filled slots in a variety of occupations, not simply agriculture. Blacks became valued workers in small industries like saltworks and tanneries. New Jersey's most ambitious industrial enterprise was its ironworks, for which slaves provided much of the skilled labor necessary for successful operation. Blacks filled part of the need for labor caused by the expiration of the terms of white indentured servants or their flight before their terms expired. Charles Read, the well-known ironmaster in colonial New Jersey, employed slave labor at a number of furnaces he built in Burlington County in the 1760s. The Andover Iron Works in Sussex County, which employed slave craftsmen, produced ironwares that were recognized for their superior quality and craftsmanship. ${ }^{8}$ 
Copper mining was another important industrial enterprise in the colony. The Schuyler family lands in Bergen County contained the most productive copper mines in New Jersey and ore mined with slave labor proved quite lucrative. Blacks were also employed in the field of transportation, at the Lambertville ferry in Hunterdon County. While most black males were used in agricultural jobs, during the winter months when crops required less attention owners utilized them in nonfarming jobs or hired out their labor to other white employers. Black females were usually domestic workers; however, as in the South, they were sometimes used for agricultural tasks. ${ }^{9}$

The versatility of slave labor in the North and diversity of occupations in which they were employed brought blacks into competition with white workers. In agriculture, the retention of African agricultural skills in hunting, animal husbandry, and pathfinding made them particularly valuable to New Jersey planters. However, industriousness and skills in nonagricultural pursuits made blacks a threat to white craftsmen and workers. Throughout the northern colonies, this fear of potentially wage-lowering competition influenced some nonslaveowning whites to favor abolition of the slave trade and even of slavery. During the years between 1686 and 1691, New York City white workers protested the use of black porters and even succeeded in obtaining a city ordinance excluding them from work. Philadelphia craftsmen in 1707 and 1737 petitioned the state assembly to exclude their black competitors from the skilled trades. The reaction to skilled blacks, whether slave or free, was divided. For nonslaveholding workers black craftsmen were a threat, but to slaveholders they were a valuable source of labor even with their enhanced ability to flee bondage successfully or plot a revolt. ${ }^{10}$

The West Jersey area of the state provides an example of blacks' accomplishments when the chains of slavery were removed. The settlement of West Jersey by Quakers and their early encouragement of manumission and eventual advocacy of emancipation resulted in the growth of a free black population. Cyrus Bustill, born a slave in Burlington County in 1735, opened a successful bakery after gaining his freedom at the age of thirty-six. Caesar Murray, also of Burlington, obtained his freedom after serving twenty-five years in bondage. Murray, a shoemaker by trade, opened up a profitable shop which allowed him to purchase the freedom of his wife and children and to build them a comfortable home. Peter Hill of Burlington County, while a young man, negotiated to buy his freedom in regular installments from his master. Hill had acquired the skill of watch and clock making from his owner, enabling him to start his own business and to buy his freedom and that of his wife. ${ }^{11}$

Slavery contributed significantly to the economic development of the state, but also produced an exploitative society lacking justice and equality for all its members. The harsher attitudes toward slavery and race relations characteristic of East Jersey prevailed in the laws after both Jersey provinces 
were reunited in 1702. A 1682 East Jersey law forbade any person to trade with free blacks and Indian or black slaves. A 1694 law prohibited slaves from hunting with guns unless accompanied by their masters. It imposed fines on people who entertained slaves in their homes for more than two hours. In addition, the law made it legal for anyone to apprehend a slave who was more than five miles from his owner's home. A 1695 law established slave courts where blacks accused of felonies or murder were tried before three county justices of the peace and a twelve-man jury. A 1704 New Jersey law stipulated burning for slaves who committed arson or murder and castration for those having "any carnal knowledge of a white woman." Although this law was disallowed by Queen Anne, the brutality necessary to maintain a system of slave labor remained apparent. A 1713 act of the legislature incorporated all of the provisions of the 1704 law, but without reference to barbaric forms of punishment. ${ }^{12}$

New Jersey's 1713 law tightening the regulation of slaves was in direct response to the fear and hysteria generated by the April 6,1712, uprising of New York City blacks. On that date, after midnight, approximately twentyfour blacks armed with muskets and pistols gathered in an orchard outside the town and set fire to a building. As whites rushed to put out the blaze, the slaves attacked, killing nine and wounding seven. The town awakened and counterattacked, forcing the outnumbered slaves to retreat. Some committed suicide rather than be taken alive. A total of seventy revolters were arrested. Some were burned at the stake, others racked and broken on the wheel, and gibbeted alive in chains. Massachusetts reacted by passing a prohibition on slave importations and Pennsylvania and New Jersey enacted duties on slave imports in order to limit the size of the black population and possible slave rebellions. ${ }^{13}$

The New Jersey law itself was modeled after New York's slave code. Aside from harsh punishments for the commission of crimes, it discouraged voluntary manumission by requiring owners to post $\$ 200$ security and pay an annual sum of $£ 200$ to each slave they manumitted. This made manumissions too costly. The purpose of the law, in addition to discouraging manumissions, was to defray any costs of government for taking care of freed slaves who were assumed to be unable to provide for themselves. The actual wording of the law reveals the hostility toward free blacks and the intensity of racial stereotypes: "whereas it is found by Experience, That Free Negroes are an idle, slothful people, and prove very often a Charge to the Place where they are." A provision of the law also gave compensation to owners of executed slaves out of concern for their financial loss in human machinery. To the colonial authorities, the loss of a slave's labor was far more serious than the loss of a slave's life. ${ }^{14}$

Despite the severity of the 1713 law, slaves continued to plot rebellions or defy authority. In 1737 , the Pennsylvania Gazette carried a story of two blacks imprisoned for plotting to poison their master. New Jersey's first 
significant slave conspiracy occurred in Somerville in 1734, also a year of slave rebellions and conspiracies in the West Indies. A group of Somerset County blacks became convinced that King George II had outlawed slavery and that they were being held illegally. They planned to rise up against their masters and seek refuge among the French and Indians, the traditional enemies of the English. A spectator at the trial of the thirty blacks arrested claimed that the conspiracy involved some several hundred slaves. The two leaders were condemned to the gallows, one slave had an ear cut off, and many others were given severe whippings. Similarly, three blacks in Hackensack were convicted and burned alive for allegedly setting fire to seven barns in 1741, shortly after New York City had experienced its famous slave conspiracy and hysterical reaction. Fanned by the fears that a New York insurrection or conspiracy would cross the Hudson, the hysteria had spread to northern New Jersey. ${ }^{15}$

The dilemma facing New Jersey by the mid-eighteenth century was one of security versus profitability. In 1713, probably in reaction to the New York slave insurrection of the previous year, the New Jersey legislature passed a $£ 10$ temporary duty on slave importations. However, the desire for profits led the council to veto a duty passed by the assembly in 1744 because the projected shortage of labor would cause great hardships. Black labor proved too valuable and at mid century profits weighed more heavily than security. In the 1760 s, New Jersey attempted to place duties on slave importations only to have them disallowed by the British government on a technicality. Finally, in 1769 , a $£ 15$ duty was placed on the importation of slaves. Security considerations augmented by the decline in the market for slaves in the northern colonies in the late 1760 s culminated in the reduction of African importations. ${ }^{16}$

Economic and security issues were not the only factors responsible for the tariff on slave importations. The moral objections to the slave trade and slavery itself by West Jersey Quakers like John Woolman and John Hepburn contributed, in some degree, to the climate for reduction of slave importations. As early as 1715, Hepburn told his fellow Quakers and Christians in the colony that they risked eternal damnation by their slaveowning practices. John Woolman, a tailor and storekeeper from Mount Holly, forcefully pointed out the contradiction between Christian teachings and slaveholding in a classic antislavery tract, "Some Considerations on the Keeping of Negroes," published in 1754. Woolman affirmed the dignity of Africans, Indians, and those enslaved at a time when religion and government failed to acknowledge their humanity. The efforts of Woolman and Hepburn along with economic and security factors were preparing the stage for the abolition of slavery. ${ }^{17}$

With the onset of the Revolutionary crisis in 1775 and the evolving confrontation with England, efforts by New Jersey Quakers to introduce a gradual abolition bill and other bills to lessen the burden of slavery and race 
on blacks were temporarily discontinued. Governor William Livingston postponed his appeal to the legislature to free the slaves until the Revolutionary conflict was over. Yet the remaining life of the slave-labor system in New Jersey was quite short. By the time of the American Revolution, slavery had become less essential to the economic life of the colony. The increase in the number of small farms, white indentured servants, and white wage earners reduced the reliance on slave labor. As the New Jersey economy matured in the second half of the eighteenth century, blacks were increasingly excluded from skilled trades and relegated to farming and domestic service. Employers began to manifest a clear preference for white over slave or free black craftsmen. By 1754, black slaves had been replaced by Irish and Welsh miners in the Schuyler mines. With the end of the French and Indian War in 1763, the demand for white militia troops decreased, allowing white laborers to achieve prominence in the state's economic life. The decline in importance of slavery between 1750 and 1804 is evidenced by the efforts of slaveholders to sell their slaves, or emigrate with them, to the South. In the early colonial years, runaway white servants were more common than fugitive slaves, but by the eve of the Revolution runaway slaves had become as common as runaway servants. ${ }^{18}$

The "natural rights" philosophy promulgated during the Revolutionary crisis tipped the scales in favor of emancipation. Yet emancipation in the northern states did not produce equality or total freedom.

\section{The Revolutionary War and Emancipation in New Jersey}

The rhetoric of the Revolutionary period contained numerous references to British attempts to eliminate colonists' liberty and reduce them to the status of slaves. Although the enslavement imagery used by patriots was an exaggeration characteristic of the propaganda battles, it at least forced a number of people to confront the contradiction between the real enslavement of blacks and the principles of liberty for which the Revolution was fought. ${ }^{19}$ John Dickinson, a Pennsylvania opponent of British policies, clearly made the comparison: "Those who are taxed without their own consent...are slaves. We are taxed without our consent... We are therefore-slaves." The anti-British Sons of Liberty passed resolutions terming the Stamp Act a plot to enslave Americans. Rev. Nathan Niles preached a 1774 sermon linking the plight of enslaved blacks to that of oppressed colonists, and pointed to emancipation as the solution to the contradiction: "For shame, let us either cease to enslave our fellow-men, or else let us cease to complain of those who would enslave us." Before the American Revolution concluded in defeat for England, a number of those most active in the cause of independence for the colonies recognized the impossibility of reconciling the practice of slavery with their professions of freedom. ${ }^{20}$

New Jersey's most forceful critics of slavery during the colonial era came from the Quaker communities in Burlington, Gloucester, and Salem counties. 
Quakers petitioned the colonial legislature in 1773 and 1774 to end slave importations and adopt measures encouraging voluntary manumission. While these efforts to stimulate emancipation continued into the Revolutionary period, abolitionist sentiment waned in 1775 and 1776 as bills to ameliorate the condition of blacks and provide for gradual emancipation were disregarded by state officials and West Jersey Quakers. While the conflict between the colonies and Great Britain ultimately stimulated the growth of the "natural rights" philosophy which contributed to the abolition of slavery in the northern states, the most immediate effect of the war was to delay emancipation. The New-Jersey Gazette opposed emancipation on the grounds that slave labor was essential to the economy and the war effort. With many white males enrolled in the army, many white families were dependent upon slave labor for their livelihood and their ability to provide money and supplies for the army. Opponents of emancipation argued that free blacks would refuse to work and become an unstable criminal element plundering the countryside. Proslavery patriots greatly feared that emancipation would lead free blacks to revolt and establish a state of their own with blacks ruling over whites. ${ }^{21}$

The experience of free blacks in colonial New Jersey does not support these fears, for free blacks were diligent workers and few, if any, had any desire to establish a black state. The committee of correspondence of Shrewsbury and Freehold, coordinating patriot opposition to the British in the area, in 1775 ordered militia officers to confiscate all arms in the hands of free blacks and slaves. On July 5, 1776, Samuel Tucker, president of the provincial Congress, requested the Continental Congress to relieve the province of the responsibility for prisoners of war in New Jersey because of the need to control the threatening situation of blacks arming themselves in Somerset County. Limited manpower reserves in a county 15 percent black increased colonial fears of black uprisings and plots with Loyalist elements. Whether real or imagined, these fears revealed a fundamental inability to perceive emancipation as a useful strategy for increasing black moral support and even military involvement in the Revolutionary cause. ${ }^{22}$

Belief that slavery was economically and militarily necessary to the war effort only partly accounts for the decline of the abolitionist movement during the Revolutionary War. Many citizens were unable to conceive of blacks as equal human beings and of America or New Jersey as a multiracial society based on equality. In 1774 the citizens of Perth Amboy petitioned Governor William Franklin of the province of New Jersey to refrain from supporting a bill to make voluntary manumission of blacks easier on the grounds that blacks "are a Very Dangerous People to have general freedom in any Providence in his majasties Dominions." According to the petitioners, slavery would be more difficult to maintain if the bill were passed, as blacks "will then have time to Consult any Plan thay Please to Lay, to invade the inhabitance and accomplish thair un-humen Designs" reducing 
whites to a similar degraded and subservient status. In 1778 William Livingston, the first governor of the state, proposed that the New Jersey Assembly abolish slavery. The Assembly opposed his efforts and Governor Livingston postponed his appeal for abolition. Support for the property rights of slaveholders and the continuation of beliefs in black inferiority combined to delay emancipation in the state until after the American Revolution. ${ }^{23}$

America's war for independence occasioned numerous changes in policies on black enlistment in the patriot cause. Blacks served in northern militia companies in engagements at Lexington and Concord in April 1775 and at the Battle of Bunker Hill. The early use of black soldiers did not continue and within ten months after Lexington and Concord a pattern of exclusion emerged. Most blacks were slaves and colonists believed blacks' enlistment violated the property rights of their masters. They also feared the army would become a refuge for runaway slaves. The army's Adjutant General instructed recruiting officers not to enlist any vagabonds or blacks. At a council of war in Cambridge, Mass., in 1775, eight generals agreed on a policy of exclusion of both free blacks and slaves. The Continental Congress decreed that already enlisted free blacks might reenlist, but refused to accept any new black volunteers. By the summer of 1776, a policy of racial exclusion had become the norm in the Continental Army. Yet, before the year came to an end, doubts arose as to the wisdom of excluding black enlistments. ${ }^{24}$

British and American needs for troops forced changes in the recruitment policies of both sides and the British initiative in recruiting black troops stimulated Americans north of the Potomac to reverse their policy of racial exclusion. The Royal Governor of Virginia, John Murray, Earl of Dunmore, issued a proclamation on November 7,1775, promising freedom to slaves of disloyal masters if they would flee the plantations and join his forces. Dunmore's motivation derived from military necessity and manpower shortages, rather than from abolitionist tendencies. Within the first week, approximately 300 blacks made their way to Dunmore's forces and formed the "Ethiopian Regiment" within his army. If not for the smallpox epidemic which infected his army, it is estimated that Dunmore would have acquired 2,000 black followers rather than the 800 slaves who eventually joined his forces. Dunmore became a hero among blacks, although he offered freedom only to slaves of the rebel patriots and as governor had with held his signature from a bill to outlaw the slave trade. Paradoxically, the patriots viewed Dunmore's proclamation as another example of British tyranny while blacks who formed the "Ethiopian Regiment" were motivated by the same love of liberty which led the colonists to revolt against England. ${ }^{25}$

Difficulties in raising volunteer forces after the first year of the war led to decreasing opposition to the enlistment of free blacks. The use of black troops gained many supporters in 1777 when Congress began to establish troop quotas for the states. State recruiting officers were inclined to use 
blacks to fill quotas whenever possible and Washington and his generals accepted troops the states sent regardless of color. Black recruitment by the New England states became prevalent after 1777. Through wartime legislation New Jersey became one of the states with racially mixed ranks. The New Jersey Militia Act of 1777 allowed the enlistment of free blacks, limiting enlistments to men between the ages of fifteen and fifty "not being slaves." Later legislation even contained the possibility of employing slaves in military service, which was opened to "all able bodied effective recruits." Servants, minors, and apprentices were exempted, but the law did not exclude black men or slaves. The New Jersey Militia Act of 1781 simply required service from "all men sixteen to fifty." A number of slaves who hoped that participation on the side of the revolutionists would lead to manumission joined their owners in the patriot cause. While the majority performed in noncombatant roles like driving wagons for the Continental Army, a smaller number served as soldiers against the British. Others provided valuable intelligence to the local militia. In New Jersey as in other northern colonies, opposition to military service of slaves was greater than to that of free blacks. ${ }^{26}$

The Continental Army at Trenton employed a number of blacks as wagon drivers, probably because many white farmers were reluctant to leave their farms. Blacks were listed in the records as among those providing the army with food provisions. Despite General Washington's warning against using black soldiers as teamsters for fear they would flee to the British with the wagons and horses, there is no record in New Jersey of black desertion to enemy lines. It is not known whether these men were slaves or free. However, records indicate that both slaves and free blacks served as soldiers on the patriot side. Oliver Cromwell, a slave from Burlington County, served as a private in the New Jersey Continental Line for a lengthy period from 1777 to 1781 . Cromwell fought in the battles of Trenton, Brandywine, Princeton, Monmouth, and Yorktown and received a federal pension. Jacob Francis also received a pension for his service in the Hunterdon County militia between 1777 and 1781. As Frances Pingeon notes in her study of New Jersey blacks during the Revolution: "James Array of Readington, a descendant of one of the few landowning black families of New Jersey, served in the Continental Line and the Hunterdon County militia." Prince Whipple, a "free-born native African," crossed the Delaware with General Washington on December 25-26, 1776, and also served as Captain Abraham Whipple's bodyguard. Samuel Sutphen, a slave from Somerset County, participated in numerous battles against the British in New Jersey and New York between 1776 and 1780. He served with Captain Lane and Colonel Frelinghuysen at the battle of Long Island and his memoir is one of the best accounts of the war in New Jersey from the ordinary soldier's viewpoint. ${ }^{27}$ 
Sutphen's participation in the war illustrates simultaneously the valor of some of New Jersey's black soldiers and the inconsistent way authorities rewarded black service. The state legislature on at least three occasions, after confiscating the property of a Loyalist, granted freedom to a slave who had performed military service. Sutphen, on the other hand, who had joined the war effort in place of his owner, Caspar Berger of Readington, was not manumitted. He served for twenty years after the conclusion of the war before finally being allowed to purchase his freedom. Most New Jersey slaves experienced little change in their status after the Revolution, but New York and Rhode Island freed slaves for military service in the patriot cause. In Connecticut, the courts ruled that enlistment with the master's consent should result in automatic freedom. ${ }^{28}$

During the war, British military commanders in the North attempted to take advantage of the black desire for freedom in order to supplement their manpower needs, as Lord Dunmore had done in Virginia. On June 30, 1779, British Commander-in-Chief General Henry Clinton ordered captured black soldiers to be purchased for public service and promised any black who deserted from an enemy master full security to follow any occupation he wished while in the British lines. The purpose of Clinton's proclamation of limited freedom was to entice blacks to the Loyalist side. The New-Jersey Journal newspaper reacted with characteristic racism in sonnet form:

A proclamation oft of late he sends

To thieves and rogues, who only are his friends;

Those he invites; all colours he attacks,

But deference pays to Ethiopian blacks.

It is doubtful that many slaves believed British promises of freedom, since Loyalists were some of New Jersey's largest slaveholders. Blacks most familiar with the earlier public debate over slavery may have identified with the goals of those in revolt against the English. Blacks in West Jersey, where abolitionist sentiments were strongest, were probably more likely than those in East Jersey to side with the revolutionists. ${ }^{29}$

Pro-British blacks usually came from areas near New York and from East Jersey towns where slavery was strongest and abolitionism weakest. Many slaves escaped bondage when the British occupied New York and Philadelphia. Most of the runaway slaves in New Jersey were from East Jersey towns invaded or raided by British troops. Blacks played an important role in Loyalist raids on the East Jersey coast. On June 22, 1780, a contingent of approximately thirty blacks, thirty-six Queen's Rangers, and thirty refugee Tories landed at Conascung in Monmouth County. The blacks were under the command of $\mathrm{Ty}(\mathrm{e})$, a black man with the title of colonel who frequently conducted raids in the Sandy Hook area. Tye was noted for his courage and was eventually killed in battle. Capt. Thomas Ward, a Loyalist of Bergen 


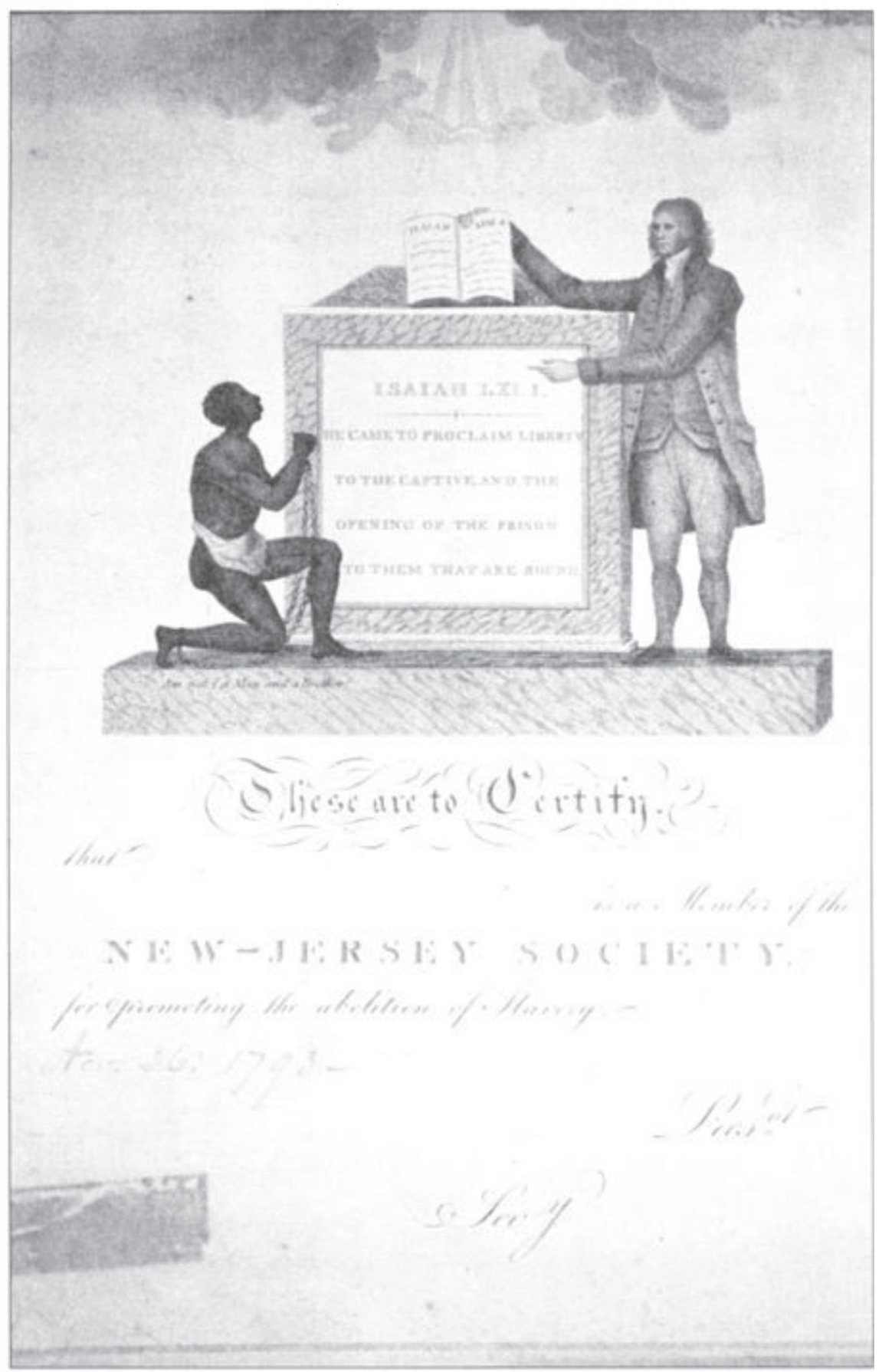

Fig. 1. A membership certificate of the New Jersey Society for Promoting the Abolition of Slavery, established in 1793. (from broadsides collection in Special Collections and University Archives) 
County, commanded a group of blacks who raided Elizabethtown, New Barbados Neck, and the Bergen Hill area. In a March 12, 1777, letter Rev. Alexander Macwhorter described a raid on Newark by British forces which contained a number of black participants. Black Loyalists, like their patriot counterparts, also furnished important military intelligence. Isaac Siscoe, a free black from a family of landholding blacks in Bergen County, was an inventive agent who provided the British with useful reports of rebel activity. For blacks serving on either side, whether as substitutes for their masters or as volunteers, a major motivation was the hope of freedom upon the war's conclusion. ${ }^{30}$

If the patriot side did not fully reward all of the blacks who contributed to their winning cause, the British also fell short of their promise. The British did not desert their black supporters by complying with the preliminary articles of the Treaty of Paris (1783) ending the war, which required them to withdraw without carrying away blacks or other American property. In his evacuation of New York, Sir Guy Carleton formulated the policy that refugee blacks who had crossed the British lines before the signing of the provisional treaty (1782) were to be free and only those who came over thereafter were to be returned to their American masters. The British adopted Carleton's evacuation plan for the entire country. However, many blacks were carried off without regard for their own wishes, especially the slaves belonging to departing Loyalists. Many departing Loyalists abandoned their sick, helpless, and aged slaves to future American masters while they evacuated only the healthy and the most economically useful. As at the Continental Congress in 1776 which outlawed the slave trade for the duration of the war, both Loyalist and patriot motivation during the Revolution was heavily influenced by military and economic necessity rather than by humanitarian concern. ${ }^{31}$

The democratic ferment spawned by the Revolutionary era resulted in the formation of abolitionist societies, and in 1780 Pennsylvania passed a gradual abolition act. Following the conclusion of the Revolution, New Jersey passed laws which lessened the harshness of slavery, restricted the slave trade from Africa into the state, and made manumission easier. A 1786 law passed by the state legislature set fines for importing slaves into the state from Africa, although it allowed the importation of slaves from other states for temporary residence in the state. The act made manumission easier while simultaneously providing special and harsh punishment for freed blacks guilty of crimes. However, the law also provided punishments for masters who abused their slaves though this provision was not enforced with regularity. In 1788, New Jersey abolished special punishments for slave offenses and specified that they were to be judged and punished as offenses by other inhabitants of the state were punished. New Jersey passed legislation in $\mathbf{1 7 8 9}$ which provided that slaves could not be removed from the state without their consent. ${ }^{32}$ 


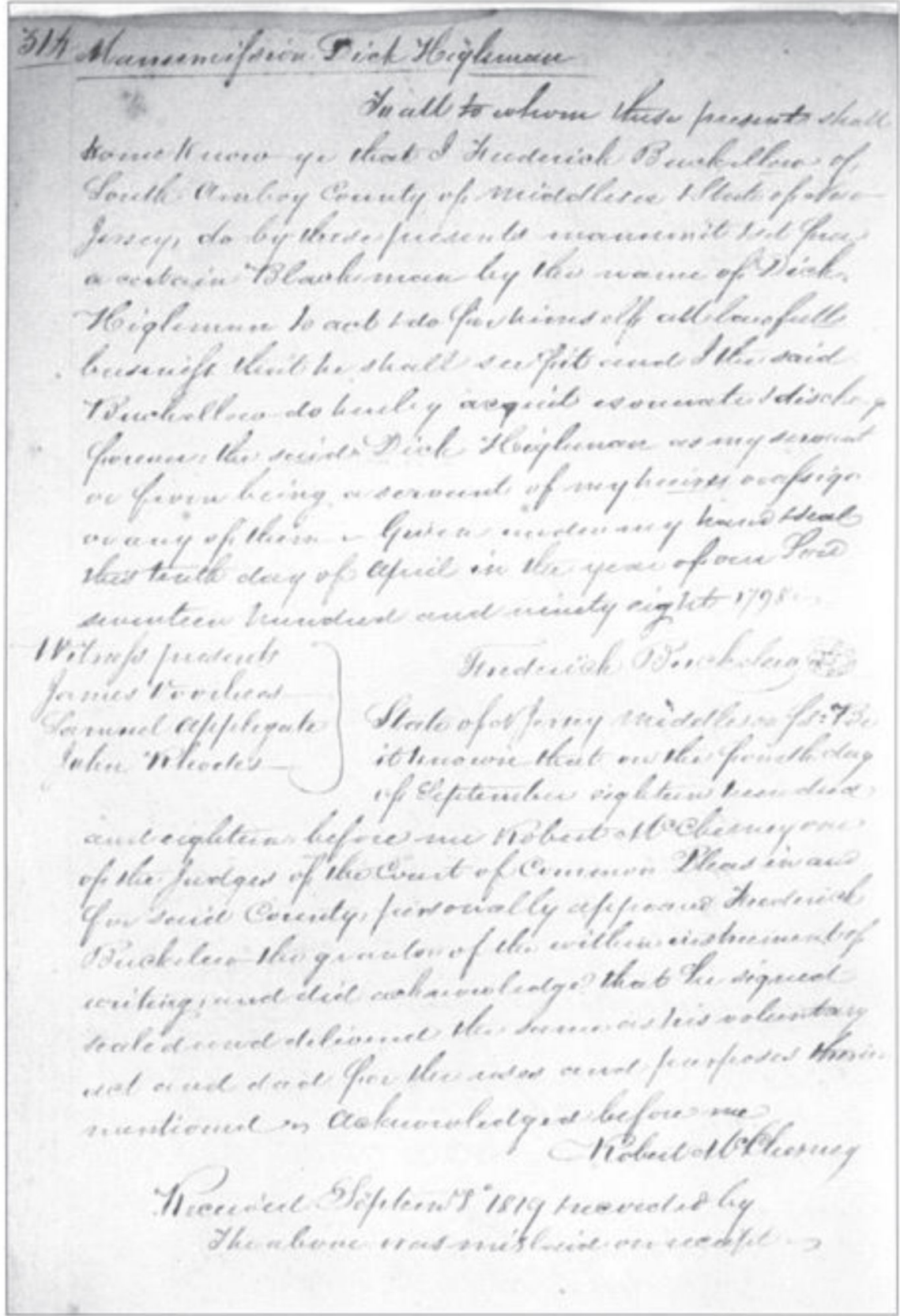

Fig.2. Photo of one page in volume of slave manunmissions in Middlesex County, N.J., 1800-1825. (from set of Middlesex County records in Special Collections and University Archives) 
New Jersey's gradual movement toward emancipation reflected the ambivalence of many of the state's residents toward the creation of a free black population, an ambivalence also manifested by the New Jersey delegation to the Constitutional Convention meeting in Philadelphia in 1787. William Paterson, a Jersey delegate to that convention, stated that the Congress under the Articles of Confederation purposely avoided the terms "slave" and "slavery" out of shame and substituted a description of the institution. Paterson was both an owner of slaves and an advocate of manumission and opponent of the slave trade, if not of emancipation. Paterson and others of the New Jersey delegation opposed inclusion in the Constitution of a provision which allowed the African slave trade to continue for twenty years before the federal government could prohibit it. Their opposition appears to be based not upon humanitarian concerns, but rather on the belief that further slave importations coupled with counting slaves for purposes of apportioning representatives in a national lesiglature would weaken a small slaveholding state like New Jersey in the proposed national legislature. Their opposition disappeared when each state was accorded equal status in the Senate under the "Great Compromise" plan developed at the convention. ${ }^{3.3}$

Despite the compromises on the slave trade and slavery reached at the Constitutional Convention, the abolitionist movement continued in the state; the New Jersey Society for Promoting the Abolition of Slavery was formed in 1793. One year later blacks gained some voting rights and in 1796 , legal residence in the state. Although emancipation bills were defeated in 1792 and 1794, abolition of slavery in neighboring states like New York in 1799 made emancipation in New Jersey appear to be just a matter of time. The growth of New Jersey's white population during and after the Revolution decreased the reliance on slave labor. Between 1786 and 1800 the population of whites increased at a rate six times that of blacks. The wage rate fell as the supply of free workers increased and slavery diminished in importance as a labor system. In 1804 the New Jersey Society for Promoting the Abolition of Slavery petitioned for the abolition of slavery of the unborn. This appeal set the stage for the state legislature's enactment of the gradual abolition law of 1804 . The law gave owners the right to the labor of slaves born after July 4, 1804, until the age of twenty-five for males and twenty-one for females at which time they would become free. New Jersey became the last northern state to provide some form of emancipation and contribute to the formation of a region committed to free labor. ${ }^{34}$

The emancipation law reflected the concern for slaveholder property rights in its gradual approach and indirect compensation of slaveowners. By 1830 , two-thirds of the 3,568 blacks still enslaved in northern states resided in New Jersey. Eighteen slaves were still listed in the New Jersey census as late as 1860 and slavery was only totally eliminated by the Thirteenth Amendment following the Civil War. The law itself allowed slaveowners to 
abandon black infants at one year of age to the local overseer of the poor, who was responsible for boarding them with households until they reached emancipation age. These guardians of black children received $\$ 3$ a month maintenance subsidy per child. Most of the slaveowners abandoned the children, only reclaiming them in order to receive the monthly payments. In effect, the law provided financial compensation and the use of black labor to masters until the age of freedom. The abandonment clause of the 1804 law consumed 40 percent of the state's budget in 1809 , before its discontinuation due to widespread fraud. Although these shortcomings in the law made abolition in the state a haltingly gradual and expensive process, it was probably necessary to achieve the bipartisan support which resulted in a thirty-four to four vote in the state assembly and twelve ţe une vote in the senate passing the 1804 law. ${ }^{35}$

lit $3 \mathrm{me}+\mathrm{H}$

\section{Beyond Bondage through the Civil War}

New Jersey's provision for the gradual abolition of slavery did not gnal the opening of a new era in the equal treatment of blacks, the acquisition of voting rights, the end of racial stereotypes, or the acceptance of the black presence in the state. Many New Jersey citizens feared that emancipation would endanger their political and economic status by eventually increasing the large free black population. For many, the law threatened racial purity and placed white workers at a competitive disadvantage vis à vis black laborers who would work for lower wages. The existence of a large free black population in New Jersey compounded these fears. By $1810 \mathrm{New}$ Jersey had approximately two freedmen for every slave the stite. The black population on the eve of the Civil War had increased to 25,336 out of a total population of 646,699 and was proportionally twice the size of the black population in any other free state. ${ }^{36}$

Fearful of the increasing black population, the state legislature passed an 1807 law disenfranchising black men, along with women. Perhaps due to the egalitarian spirit of the American Revolution or simply an oversight, free blacks and women had enjoyed the franchise since the Revolutionary era. The persistence of racial stereotypes and the perception of blacks as a degraded people contributed to the effort to establish a legal status devoid of political rights for the state's black citizens. With the ratification of the state's new constitution in 1844 , the franchise was restricted to white male citizens while property qualifications for voting were eliminated for whites. ${ }^{37}$

\section{The Colonization Movement}

Disenfranchisement of black New Jerseyans reflected not only an objection to black political participation, but also the inability of white citizens to conceive of the state as a multiracial society. Rev. Robert Finley of Basking Ridge, a New Jersey resident already active in the colonization effort, played an instrumental role in the 1816 founding of the American 
Colonization Society, an organization dedicated to removing America's black population to Africa and eliminating the multiracial character of the republic. ${ }^{38}$

The founding meeting held in Washington, D.C., was attended by Daniel Webster, Andrew Jackson, Francis Scott Key, and John Randolph, among others. It was chaired by Henry Clay; Supreme Court Justice Bushrod Washington was elected president of the Society. Governors, congressmen, judges, mayors, and five Ivy League university presidents attended the first meeting. Finley had a distinguished career as an educator: preparatory school headmaster, instructor at Princeton Theological Semi-

1ry, and trustee of Princeton University. The movement to colonize 'America's black population in Africa represented the organizational attempt or A A. 'ca's elite to revive Thomas Jefferson's goal of a predominantly white society free of an African presence. As early as 1777, Jefferson had proposed a black colony in the area later named the Northwest Territory. He inceived of this early colonization scheme as "the most desirable measure that could be adopted for gradually drawing off this part of our population." 39

- Two montt: after the founding of the Society, Finley left New Jersey to become president of the University of Georgia. He contracted tropical fever and died in October 1817. With the departure and death of Finley, the colonization movement in New Jersey lost headway. The provisions of the state's gradua! abolition law of 1804 suggested to many that there would be a significant increase in the free black population by 1825 . This expected increase provid $d$ the impetus for the resurgence of the New Jersey chapter of the American Colonization Society (NJCS) and its reorganizational meeting held in Princeton on July 14, 1824. Members of the state's political elite $\mathrm{v}$;re in attendance. The NJCS was reorganized by Robert Field Stockton, a Princeton graduate, distinguished naval officer, and future Democratic senator. Also in attendance were Theodore Frelinghuysen, a future senator and Whig candidate for Vice President; General John Frelinghuysen; Samuel Bayard, a Federalist state legislator and judge; Governor Isaac H. Williamson; and Charles Ewing, Chief Justice of the New Jersey Supreme Court. ${ }^{40}$

The NJCS claimed, like its parent national organization, to desire the emancipation of all the slaves in America and the establishment of a colony of free blacks which would Christianize Africa. The New Jersey legislature endorsed a colonization resolution to achieve these goals in October 1825. Since neither the NJCS nor the state legislature favored governmental abolition of slavery, it is doubtful that southern slavery could have been eliminated through voluntary manumissions by slaveholders enjoying the financial rewards of a profitable economic system. Commodore Stockton maintained that emancipated blacks could not be assimilated into a modern and more advanced American society, asserting that the abolition of slavery 
without colonization would result in "the letting loose upon the community of the United States such a body of men, who had no important interests at stake, nor any common concern in the permanency of our institutions." Although the NJCS held additional yearly meetings from 1825 through 1827, declining funds and insignificant progress toward colonization resulted in a decade of organizational lethargy. ${ }^{41}$

In 1838 the NJCS was revived on a wider scale through the efforts of William Halsey of Newark, the new colonization agent for the state. Halsey succeeded in winning the support of several hundred middle- and upperclass New Jersey residents, some three hundred of whom attended a public meeting in Newark on June 30,1838. With increased financial support, the NJCS purchased a ship, the Saluda, and in 1853 purchased 160,000 acres of land for the establishment of a New Jersey settlement to be added to the Liberian colony founded by the American Colonization Society (ACS). Yet the effort of the NJCS, like those of the national organization, failed to colonize significant numbers of blacks. The ACS colonized only 8,204 blacks between 1820 and 1853 . Of these, 592 were residents of northern states, and only twenty-four were from New Jersey. After 1853, only seventy-eight emigrated to Liberia. Aside from the failure to obtain substantial emancipations from southern slaveholders, the opposition of the free black population doomed the efforts of the Colonization Society to promote black emigration. ${ }^{42}$

\section{Exclusion of Blacks}

At the time of the revival of atrempts by the NJCS to promote black emigration in the late 1830 s, other New Jersey leaders sought to restrict the civil rights of black residents and prevent the immigration of fugitive slaves. An 1837 bill entitled "A Further Supplement to an Act Entitled an Act Respecting Slaves" was passed by the New Jersey Assembly. The legislation had been introduced by assemblymen from Cumberland County responding to petitions from South Jerseyites complaining of the influx of fugitive slaves from the South into southern Jersey communities, condemning "these vicious intruders" and their negative influence upon black residents, and making unsubstantiated charges that these two groups were guilty of constant attacks upon the property of white residents. ${ }^{43}$ The bill was rejected by the Council as a violation of the constitutional rights of New Jersey free blacks, but would have required all free blacks and mulattoes in the state to register with their county clerks and all blacks from all other states to present certificates of manumission to the local authorities in order to remain in New Jersey. It expresses white fear of black migration to the state and the desire to subject the state's Afro-American population to discriminatory regulation.

Northern New Jersey legislators supported the bill despite the limited impact any potential influx of blacks would have had on their counties, 
which had actually experienced declines in the black population since 1800 . The northern counties of what was formerly East Jersey had contained the greater number of slaves in the state during the colonial era and harbored an undisguised hostility to blacks, either slave or free. In the nineteenth century, northern Jersey's antiblack attitudes may have been intensified by the growing economic ties between the state's industrial sector (e.g., mills) and the South's plantation cotton economy. The southern counties of formerly West Jersey accounted for seven of the twelve votes against the bill. Quakers in these counties, perhaps reflecting their traditional antislavery opposition, petitioned against the bill. ${ }^{44}$

\section{Black Response and Antislavery}

Afro-Americans did not react passively to the colonization efforts of the ACS, the attempts to prevent black migrants from entering New Jersey, or their exclusion from the franchise under the new state constitution of 1844. These efforts to reduce the black presence and restrict black civil rights galvanized black political and social action around a common goalthe quest for equality. Within months after the founding of the ACS, approximately 3,000 blacks gathered in Philadelphia in August 1817 and condemned the organization's colonization plan as a scheme which would solidify slavery in the United States by removing slavery's most vigorous critics, free blacks. They predicted that colonization would encourage further restrictions against free blacks in America in order to promote their emigration to Africa. Since for a substantial number of blacks Africa was a memory dimmed or stereotyped by the passage of time, the sense of kinship with those still in bondage was an important source of anticolonization sentiment. ${ }^{45}$

Meetings and conventions of free blacks from 1830 to the outbreak of the Civil War would condemn the colonization efforts of the ACS. Yet emigration to Canada under black leadership received favorable comment in the records of numerous black conventions. Afro-Americans were fearful and disillusioned after their exclusion from the political process and because of depressed economic status in most northern states. New Jersey delegates John Arnold and Sampson Peters, at the first Convention of the American Society of Free Persons of Colour held in Philadelphia in 1830, concurred with convention sentiment for a Canadian settlement. At the 1832 Convention, Thomas D. Coxsin of Gloucester County aided in the preparation of a report strongly condemning the ACS for coercing free blacks to emigrate to Africa. Reflecting the ambivalence common in the black community toward the future in America, Coxsin simultaneously proposed investigating the purchase of land in the province of Upper Canada. The Convention feared that such a move would encourage the ACS to seek laws to expel blacks and merely appointed an agent for Upper Canada to aid those fleeing oppressive laws in America. Thomas Banks, a New Jersey delegate to the 
1833 Convention, prepared a resolution excoriating the ACS and indicating that blacks "feel themselves aggrieved by its very existence and consider it to be devoid of any true sense of benevolence." 46

The renewed activity of the NJCS in the late 1830s prompted blacks in the state to oppose colonization and hold a meeting on the topic in Newark in January 1839. After strongly rejecting the principles and plans of the ACS, the group commissioned two leading black clergymen orators to write a rebuttal to ACS speakers and literature. Samuel E. Cornish, pastor of the First Presbyterian Church in Newark, and Theodore S. Wright, a Presbyterian minister from New York City, published a pamphlet which became a classic anticolonization statement. It took the form of an 1840 letter addressed to Theodore Frelinghuysen, president of the NJCS, and Benjamin F. Butler, former U.S. Attorney General and U.S. Attorney for the Southern District of New York. Cornish and Wright vehemently denied Butler's assertions that the colonization project received great support from blacks, noting that Christianization and colonization of the western hemisphere had decimated the native Indian population. Furthermore, colonization was denounced as a slaveholders' scheme to reinforce slavery in America. The authors appealed to whites to refrain from discrimination and allow blacks to improve their own condition. They argued that under these conditions, white prejudice against blacks would not prove immutable, necessitating colonization in Africa as ACS officials maintained, but rather would diminish with the passage of time and with the increase in status of blacks. Hundreds of copies of the pamphlet published in Newark were circulated in New Jersey. Blacks in Westfield, Rahway, Elizabeth, Paterson, Newark, Trenton, and New Brunswick sent anticolonization petitions to the state legislature in the early $1840 \mathrm{~s}^{47}$

Black opposition to colonization not only thwarted the efforts of the ACS to recruit colonists, but also influenced many white abolitionists to reject colonization. The conversion of William Lloyd Garrison, a leading white abolitionist, to an anticolonization position in the early 1830 s paved the way for the antislavery movement to move in the more militant direction of immediate and uncompensated emancipation and away from the conservatism of gradual emancipation and compensation for slaveholders. This new militancy found expression in the state with the formation in 1840 of the New Jersey State Anti-Slavery Society. For the most part, New Jerseyans remained indifferent or frequently hostile to abolitionists and the antislavery cause. Pockets of antislavery sentiment existed in New Brunswick and Belleville, where the well-known abolitionists Theodore Dwight Weld, Angelina Grimke Weld, and Sarah M. Grimke settled in 1840. In 1841 the New Jersey Anti-Slavery Society vigorously criticized the Methodist Episcopal Church and the Presbyterian Church for their support of racial inequalities and nonsupportive attitudes toward the cause of emancipation. 


\section{cionotitution}

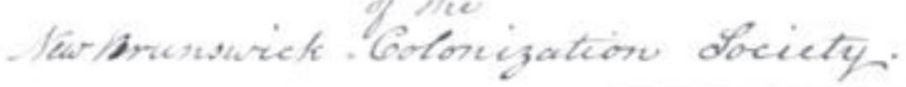
Adriled tale so:s8s.

\section{tuticle}

Hiw dociety oficell be called the "NowHransurcte Golonijation Tacuete" and diale be

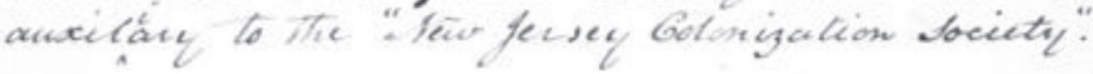

The $\quad$ IS

The annual subscifution of ans swen reale crastitute an indeicduac a menbe of this sovely, and the farment at any one tive of twonty dellare a menberfor lige.

Whe pikcen of the socicty shale be a

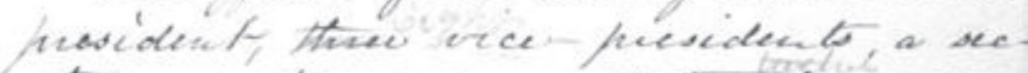

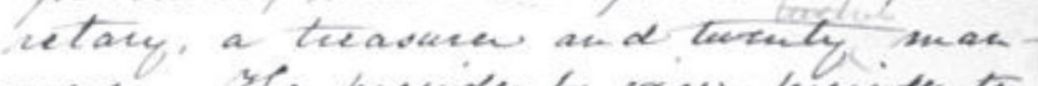

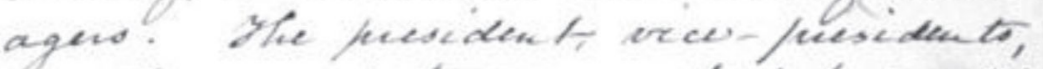

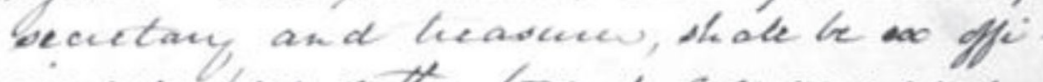
cis sumber of the brand of managen. thy surw of thes, includeng. Ho pusi dent or one of the excerpesideats, thale be a quoweres to do buaness. Haeg shate have the powe to afprovit an excese-

Fig. 3. Photo of the first page of the constitution of the New Brunswick Colonization Society, formed in $\mathbf{1 8 3 8}$ as a part of the New Jersey Colonization Society. (from New Brunswick Colonization Society records in Special Collections and University Archives) 
The Society passed a resolution requesting the legislature to improve the legal status of blacks in the state and provide equal access to suffrage. ${ }^{48}$

The concern of the New Jersey Anti-Slavery Society for the disenfranchised black citizens of the state was justified. The legal status of free blacks in the northern states had deteriorated throughout much of the antebellum period. An 1807 law had excluded free black males from the franchise they had enjoyed since the Revolutionary era. Liberalized state voting requirements eliminating property qualifications were associated with the democratization of politics in the Jacksonian era but did not produce political equality for blacks. New Jersey's 1844 constitution eliminated property qualifications for voting, but also restricted the franchise to white male citizens. In Connecticut, an 1814 law limiting voting to white males was enshrined in the state constitution in 1818. A Pennsylvania 1837 court decision declared that blacks were not freemen and therefore ineligible to vote. A year later that state's constitution limited the franchise to white males. In 1822 Rhode Island barred blacks from the condition of freedom necessary for the franchise. In 1821, the new state constitution of New York instituted property qualifications for black voters. ${ }^{49}$

Blacks initiated a public campaign against the exclusive enfranchisement of white males in the new New Jersey state constitution of 1844 . In 1849 , blacks in Salem and Gloucester counties petitioned the state legislature to remove the voting restriction on them, noting parallels with the Revolutionary War era opposition to taxation without representation, since free blacks were taxpayers but could not vote. The additional contradiction that blacks were excluded from the vote but recently arrived and naturalized foreigners could vote was noted by the South Jersey petitioners. In August 1849, a Convention of Coloured Citizens of New Jersey meeting in Trenton resolved to support a petition campaign among blacks and sympathetic whites to eliminate the "white" provision from the state Constitution. Three black clergymen drafted the major convention address to the citizens of New Jersey: Joshua Woodlini(g) of Burlington, W.T. Catto of Trenton, and Ishmael Locke of Camden. Drawing upon the natural rights philosophy contained in the Declaration of Independence, they asserted that all men were entitled to liberty, property, and political participation. Soon after the convention ended, numerous profranchise petitions were sent to the legislature by blacks in Gloucester, Cumberland, Mercer, Middlesex, Monmouth, and Salem counties. ${ }^{50}$

One of nineteenth-century America's most famous blacks, John S. Rock of Salem County, a dentist and physician who graduated from the American Medical College in Philadelphia, raised his voice and pen against the disenfranchisement of the state's black population and advocates of colonization. In his 1850 address to the citizens of New Jersey he invoked many of the arguments made by black petitioners and the 1849 New Jersey black 
convention. Rock revealed the contradiction between national ideals, black military contributions, and the reality of black exclusion from the political life of the state. Ultimately Rock left New Jersey for Massachusetts, where he studied law and was admitted to the bar in 1861. In 1865 he became the first black attorney accredited to practice before the U.S. Supreme Court. Had he remained in New Jersey, Rock would have been denied the vote and excluded from political life. ${ }^{51}$

\section{Underground Railroad}

During the antebellum era, while free blacks in the state labored against colonization, disenfranchisement, job discrimination, and poverty, hundreds of slaves escaped from bondage in the South and the border states of Maryland and Delaware and made their way to the quasi-freedom of northern states like New Jersey. A network of routes, safe houses, and abolitionist sympathizers acting as conductors formed the Underground Railroad. The state had three main routes: from Camden to Burlington, following the Delaware River; from Salem through Woodbury, Mount Laurel, and Burlington to Princeton; and through Greenwich, with stations at Swedesboro, Mount Holly, and Burlington directing the runaways to the Camden route. At Greenwich, on the very edge of a slave state, fugitive slave settlers were given sanctuary by their Quaker protectors. Harriet Tubman, one of the most famous conductors on the Underground Railroad in the 1850s, had escaped from bondage in Maryland in 1849 and was familiar with the geography of the border and upper states. During the summer of 1852, she worked as a cook in a Cape May hotel from which she probably continued her role as conductor by helping slaves from Maryland and Delaware to escape across Delaware Bay to Cape May and other places of refuge. She aided in the escape of perhaps as many as 300 slaves. $^{52}$

Despite the work of Tubman and other blacks, New Jersey was not a sanctuary for escaped slaves. In 1826 the New Jersey legislature provided for the return to their owners of fugitive slaves residing or caught in the state. The 1833 case of Johnson $v$. Thomkins reveals the difficulties faced by runaway slaves seeking freedom in those northern states with laws compelling their return to their owners. A New Jersey slaveowner reclaimed his slave from the premises of a Quaker, John Kenderdine of Montgomery County, Pennsylvania. Before the slaveowner could return to his home state, his party was overtaken, a violent skirmish ensued in which the slaveowner was injured, and the party was taken into custody and prosecuted. The trial ended in the acquittal of the slaveowner from New Jersey; the seizure of the runaway slave was found justifiable. In 1837, the law was amended to allow a review of alleged fugitive slave cases by three justices and a jury trial if necessary. In the same year conservatives unsuccessfully attempted to pass a bill in the legislature requiring free blacks to register 


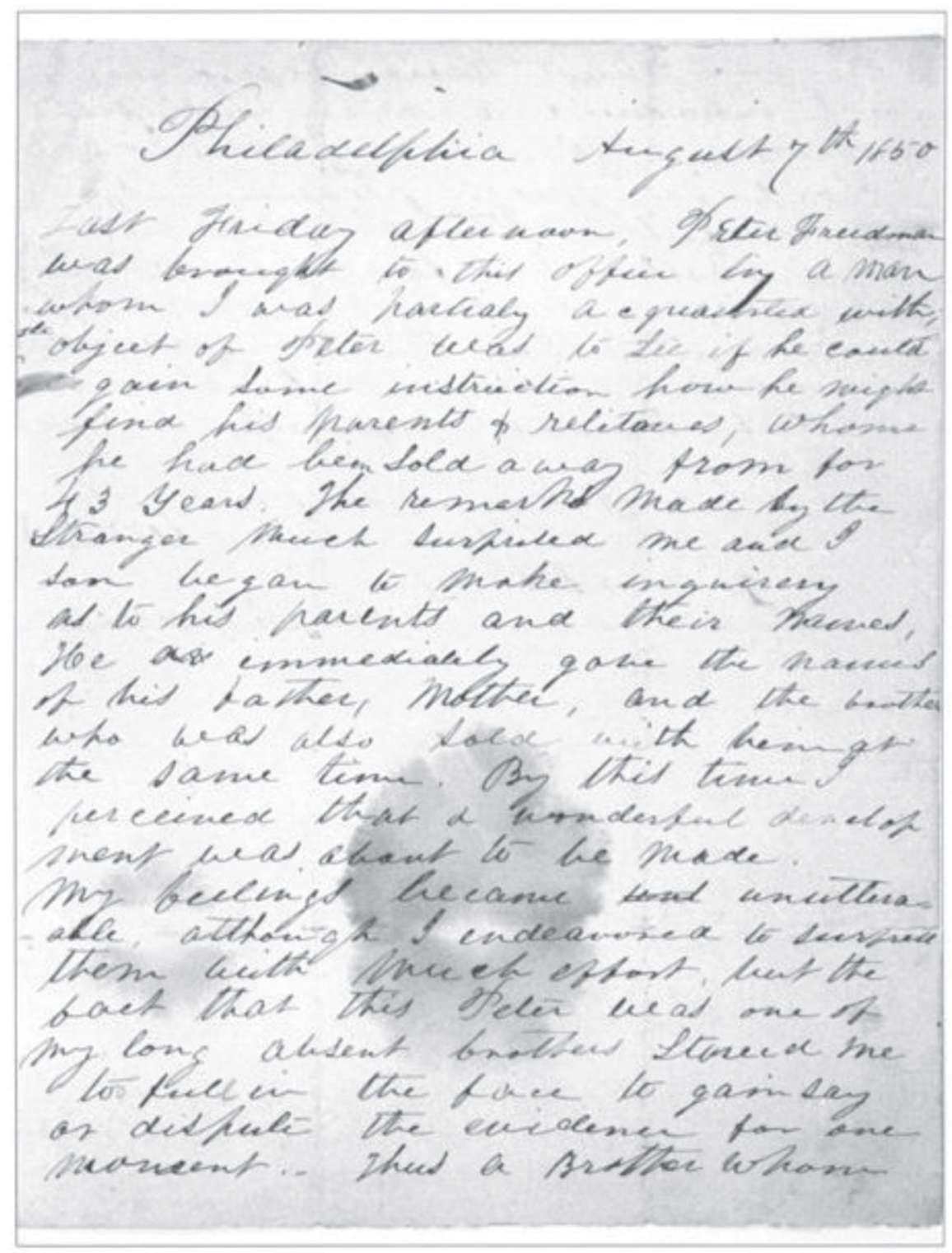

Fig.4. In this letter, written August 7, 1850, William Still, a clerk at the Philadelphia Anti-Slavery Office, describes his joy at being united with his long absent brother, Peter. (from Peter Still papers in Special Collections and University Archives) 
with county clerks and blacks from other states to present certificates of manumission to local authorities. The state's antiabolitionist sentiments made successful escape for fugitive slaves to or through New Jersey dangerous. The possibility that runaway slaves would augment the population increased the fears and hostility of many New Jerseyans already hostile to the state's free blacks. ${ }^{53}$

Second only in fame to Harriet Tubman as an operative for the Underground Railroad, William Still made an immense contribution to the safety of fugitive slaves and to our knowledge of the inner workings of that conduit to freedom. Still was born in New Jersey in 1821 to parents who had emancipated themselves from slavery through escape and self-purchase. He moved to Philadelphia and joined the Pennsylvania Anti-Slavery Society. A group of Philadelphia abolitionists in 1852 formed a General Vigilance Committee to offer financial and other assistance to runaway slaves. Still headed the four-man leadership group of the Committee, and during his fourteen years of service for the Underground Railroad interviewed hundreds of escaped slaves fleeing north. On a summer day in 1850 , he discovered that the fugitive slave he was conversing with happened to be his brother. Still kept voluminous records of the interviews and activities of the Vigilance Committee, concealing them in the loft of Lebanon Seminary and in a graveyard. In 1872 he published his account of the efforts to aid runaway slaves, The Underground Railroad. While commending the altruistic actions of white abolitionist and free black Underground Railroad operators, Still focused upon the heroism and determination of the runaways. The Underground Railroad did not conduct enough slaves to significantly weaken southern slavery, but it did contribute to sectional divisions which led to the Civil War and emancipation. Still and his colleagues across the North directly helped thousands to escape, but they contributed indirectly to the emancipation of four million bondsmen. ${ }^{54}$

\section{Civil War}

The failure of political parties and leaders to resolve the issue of slavery in the western territories and the election of Abraham Lincoln led to the secession of the South and the eruption of civil war. Support for the Union was neither wholehearted nor uniform throughout the northern states. Antiwar and even prosouthern sentiments flourished in a belt stretching across the southern two-thirds of Illinois, Indiana and Ohio, most of Pennsylvania, the lower half of New York, and almost all of New Jersey. These sentiments were often expressed in antiblack measures such as opposition to the Emancipation Proclamation and to the recruitment of black troops, and proposed legislation to prevent blacks from migrating into the state. New Jersey was the only northern state to vote against Lincoln in both 1860 and 1864 and against the Thirteenth, Fourteenth, and Fifteenth amendments which respectively ended slavery, defined citizenship 
nonracially, and prohibited the denial of vote to blacks. In March 1863, just two months after the Emancipation Proclamation, the New Jersey legislature passed the "Peace Resolutions," denied Lincoln's power to emancipate the slaves, and proposed that the Union seek a peace settlement. ${ }^{55}$

Lincoln's Emancipation Proclamation, which took effect in January 1863 , intensified the opposition of his political opponents. New Jersey was the single Union state in which both houses of the legislature were controlled by Democrats. Some newspapers supported the proclamation as a military measure expected to drain Confederate troops from the battlefield to control the slave population, but did not defend the document on moral grounds. ${ }^{56}$ Newspapers critical of Lincoln condemned the Proclamation as a violation of the right of slaveholders to their human property. Joel Parker, recently elected Democratic Governor of New Jersey, predicted that the emancipation of southern slaves would lead to a large migration of blacks into the northern states which would displace white workers from their jobs. Parker and his supporters could not imagine that a predominantly rural black population desired to acquire land, become independent southern famers, reinforce familial bonds weakened by slavery, and join in the Union's campaign to beat the South. ${ }^{57}$

Opponents of emancipation were not content to list each specific economic or constitutional objection separately. By combining their various fears of racial equality and projecting them onto abolitionists, anti-Lincoln politicians and newspaper editors were able to create conspiracy theories and magnify the sense of alarm over the proclamation. One newspaper claimed Lincoln's administration preferred war to peace in order to gain control over the military and abolish slavery. Another charged that the administration had perverted a war to preserve the Union into a war for the emancipation of blacks and subjugation of southern whites. James Wall, New Jersey's leading administration critic, associated Republican Party policies on the slavery issue with the acts of Genghis Khan and George III, and with John Brown's raid on Harper's Ferry. The association of historical symbols of evil with emancipationists constituted the finishing touches to conspiracy imagery. The claim that Republican abolitionists orchestrated the nation into the Civil War and perpetuated that war in order to free slaves attributes an unrealistic control of political and historical developments to Lincoln and his party. However, it does reveal that significant elements in the state still viewed blacks as inferior outsiders in society and on the battlefield. ${ }^{58}$

This view may explain the New Jersey Assembly's passage of a bill entitled "An Act to Prevent the Immigration of Negroes and Mulattoes" on March 18,1863 , by a vote of thirty-three to twenty. The bill died in the New Jersey Senate, but its provision for deporting black migrants to Liberia or the West Indies demonstrated a continuing fear of a multiracial society. This fear was again expressed in a bill passed by the New Jersey Assembly 
in March 1864 entitled "An Act to Prevent the Admixture of Races." The bill also died in the Senate along with one to prohibit the use of funds for the employment of black troops. ${ }^{59}$

Black residents of New Jersey did not lose hope that slavery would come to an end for their brethren in the south and that equality could be achieved in the state. These ideals became evident in the support given the Union war effort by the state's black community and their rejection of colonization as a solution to the discrimination faced by free blacks. Despite political disenfranchisement by the state legislature and state constitution, relegation to the lowest paying jobs, and segregation either by custom or law, New Jersey blacks continued to struggle for equality. Alfred P. Smith, a journalist from Saddle River, wrote that blacks had fought for America from the time of the Revolution and the War of 1812 and raised a question for those like President Lincoln considering colonizing blacks in a foreign land: "Are you an American? So are we. Are you a patriot? So are we. Would you spurn all absurd, meddlesome, impudent propositions for colonization in a foreign country? So do we." Some 2,909 black Union soldiers were credited to New Jersey and saw heavy action at Fort Wagner, Chapin's Farm, Petersburg, and other battles. Since New Jersey did not establish black regiments, volunteers from New Jersey joined black regiments in other states, and it is difficult to ascertain their specific military and combat activities. Nevertheless, the contribution of New Jersey Afro-Americans to the Civil War and to the establishment of a racially egalitarian society is a matter of historical certainty. ${ }^{60}$

\section{Reunion, Reaction, and Progress: 1865-1900}

In 1865 Afro-Americans throughout the nation celebrated the defeat of the Confederacy, the end of slavery, and the beginning of the northern attempt to construct a more democratic and racially egalitarian South. The reconstruction of the war-torn nation rested upon the passage of three amendments extending political and civil rights to blacks. 'The Thirteenth Amendment reaffirmed the spirit of Abraham Lincoln's Emancipation Proclamation. The Fourteenth and Fifteenth Amendments extended citizenship and voting rights respectively to all Americans regardless of color. The Reconstruction era officially spanned the period from 1865 to 1877, and in some southern states even less than these twelve years. Yet in this brief period, freedmen made great strides in politics, electing members of their race to state legislatures and Congress. Schools established by the Freedmen's Bureau, private missionary groups, and southern states aided in the reduction of illiteracy. ${ }^{61}$

Reconstruction accomplished much but ended prematurely; many southern blacks remained poor, landless agricultural workers. A combination of southern hostility and northern indifference to racial equality resulted in the gradual elimination of the black electorate and officeholders in the South 
by 1900 . The gradual disenfranchisement of southern blacks followed the disputed presidential election of 1876 and the Compromise of 1877 which allowed the Republican Party to retain control of the presidency by agreeing to southern demands for state control of racial issues. Promises to safeguard black legal rights were soon abandoned and by the turn of the century southern state constitutions and laws established racial segregation in public accommodations, transportation, and schools. The 1896 U.S. Supreme Court case Plessy v. Ferguson declared this segregation constitutional. ${ }^{2}$ Almost from the beginning of the Reconstruction era, New Jersey mirrored the nation's ambiguous attitude toward racial equality. New Jersey laws, like the U.S. Constitution, sought to establish a color-blind society and laid the foundation for future racial progress, but in practice racial discrimination and injustice persisted.

\section{Freedom Amendments}

During the Civil War, the Democratic party slogan was "the Constitution as it is, the Nation as it was." The desire to maintain the status quo of racial oppression persisted after the war. The resolution proposing ratification of the Thirteenth Amendment was rejected by the Democrat-controlled New Jersey legislature by a twelve to eight vote along party lines. It was not until the Thirteenth Amendment had already become part of the Federal Constitution that New Jersey finally ratified the amendment in January 1866. The return of a Democratic majority to the state legislature in 1867 resulted in the passage of a joint resolution rescinding the previous ratification by the state. For some legislators, the right of defeated secessionists to own human property outweighed the right of blacks to freedom. When the Republicans won control of the legislature in 1868 the Fourteenth Amendment was ratified. However, the Democrats rescinded the measure as soon as they were returned to power. Issues of black political and civil rights never transcended partisan politics nor the long-held racial antipathies of the Democratic Party. ${ }^{6.3}$

A similar scenario developed when the Democrat-controlled legislature rejected the Fifteenth Amendment and a subsequent Republican legislature passed it. Although the amendment was not ratified by the state legislature until 1871 , its ratification by the nation in 1870 meant that Thomas Mundy of Perth Amboy became the first black in the nation to exercise the vote under the Fifteenth Amendment, on March 31, 1870. Opposition to voting by blacks erupted into a riot in Camden when black citizens attempted to cast their votes. New Jersey ultimately passed the Reconstruction amendments, but the opposition of the Democratic legislatures and of Governor Joel Parker represented a continuing belief in black inferiority. Governor Parker opposed extending the franchise to the freedmen because he feared the large black population in the southern states would vote black legislators into Congress. He warned that such "a mongrel 
government" would never prosper or function well. The pro-Democratic Newark Journal opposed voting by blacks whether they could or could not pass literacy tests. Despite strong opposition, the Fifteenth Amendment took effect and laid the foundation for New Jersey's black electorate. ${ }^{64}$

Within a year of the amendment's passage, the first black juror in New Jersey served in West Milford. Following the passage of the amendment, a huge celebration and the first large-scale parade by blacks occurred in New Brunswick on May 26, 1870. At the celebration, the address which drew the greatest attention was that of William Whipper, a black abolitionist leader in the antebellum era, who in $1835 \mathrm{had}$ been a founder of the American Moral Reform Society, an outgrowth of the early national Negro conventions. The organization had been formed to encourage Christian morality, thrift, temperance, and hard work among blacks. Participants at the celebration heard Whipper stress not so much the virtues of the Protestant ethic, but rather the necessity of race pride and black contributions to the preservation of American freedom throughout the nation's wars. Whipper expressed the Afro-American desire for equality during Reconstruction and emphasized the role in the struggle for liberty of militants like American slave revolt leaders Denmark Vesey and Nat Turner, Haitian slave revolt leader Toussaint L'Ouverture, black abolitionist David Walker, and the militant white abolitionist John Brown. The audience responded warmly to Whipper's eloquent remarks depicting past heroes in the struggle against slavery and the hope for a new and equal status in the nation. ${ }^{65}$

The passage of the Fifteenth Amendment reflected not only the efforts of white people of goodwill, but also the determination of blacks to secure their rights. In 1864, a National Convention of Colored Men met in Syracuse, N.Y., and formed the National Equal Rights League to push for racial justice and equality. Five black men from New Jersey attended: William Day and Edwin Freemen of Newark, Thomas G. Gould and Thomas Cooper of Trenton, and D.P. Seaton of Morristown. The following year a similar group of men in New Jersey held a convention to launch the Equal Rights League in the state. This was probably the first statewide organization of blacks to attack segregation and disenfranchisement. In an address to the convention, Samuel G. Gould noted that the exclusion of blacks from the political process "had retarded our progress and elevation." 66

The state's Afro-American population did not stand passively by in the struggle for political equality. While they had to wait until the nation ratified the Fifteenth Amendment before they could vote, courageous individuals mounted a campaign to gain the vote soon after the war ended. Rev. Charles H. Thompson and Abraham Conover of Newark had been refused enrollment as voters by the city registrar following the Civil War. Through an organization known as the state Executive Council, they initiated a suit in the Supreme Court of New Jersey and the U.S. Circuit Court to end the disenfranchisement of Afro-Americans. Despite the passage of the 
Fifteenth Amendment and the beginning of Afro-American voting in New Jersey in 1870 , conservative elements stubbornly resisted efforts made after 1871 to eliminate from the state Constitution the word "white" regarding voting requirements. Finally, in 1875, the word was stricken from the document and New Jersey achieved a color-blind Constitution. ${ }^{67}$

\section{Education and Segregation}

The late 1860 s and early 1870 s were a period of reconstructing the defeated South into a more egalitarian society, but also of northern society's remolding itself into a more racially democratic community. As early as 1832, Trenton had announced the opening of a black school, as did Middletown in Monmouth County in 1833. In 1843 Camden ordered the opening of a "colored" school to be operated under the same regulations as the white schools. Shortly after Jersey City opened its first public school; blacks sought and were denied admission. In the fall of 1848, a separate school for black children was organized. Elizabeth Town had placed black children in separate schools by 1859 and in that same year Newark rejected admitting black children to the public schools. The movement for public schools in New Jersey, as in other pre-Civil War states, expanded educational opportunities for blacks, but within a framework of segregated schools. ${ }^{68}$

During Reconstruction, attempts to establish racially mixed schools echoed those for legal and political equality in northern New Jersey. Two years after Thomas Mundy cast his vote in 1870, the city of Newark desegregated public schools, thereby reversing the trend toward separate schools for blacks established by the city School Committee in 1836. In the 1870s Elizabeth Town, Jersey City, Paterson, and Passaic abandoned separate schools for blacks. By 1877 , approximately half the segregated schools in the northern counties had been eliminated. Racial justice was not the only consideration in the integration of the public schools. The expense of operating dual school systems for such a small black population was onerous. The heavy influx of European non-Protestant immigrants considerably weakened any chance of maintaining ethnic and religious homogeneity. With more than a quarter of the population of Essex County, a third of Hudson County, almost a quarter of Union County, and nearly a fifth of Middlesex County foreign-born, the integration of relatively small numbers of black children into the schools had a minimal effect upon an already heterogeneous school population. ${ }^{69}$ It is ironic that the immigrants who often displaced blacks in industrial jobs contributed to their integration into the public schools.

The southern counties continued the practice of segregated schools. Although the Constitution of 1844 decreed that the state should provide thorough and efficient free public education for all children, it did not prohibit segregated schools. In 1881, the state legislature passed a law 


\section{HISTORY AND PROCEEDINGS}

ATTENDING THE PRESENTATION OF A MEDAL TO

ThOMAS PETERSON-MUndy

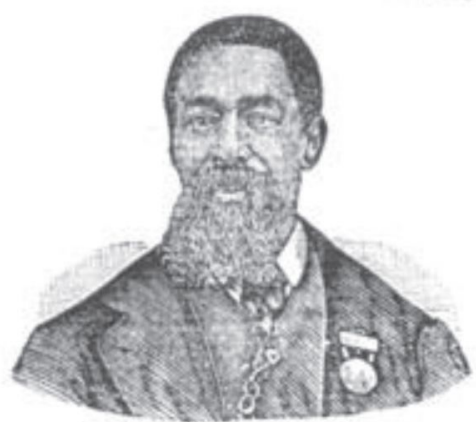

Decontion Day, May 30tb, 1884.

IN THE CITY OF PERTH AMBOY, N. $d$.

In commemoration of his having been the First Colored Citizen in the

Unitol States to cast a vote under the Fifteenth Amendment

WITH ADDRESSES BY

HON. WILLIAM PATERSON

AND OTHERS

PEЕTH AMBOY, $\mathrm{X}, \mathrm{J}$.

THE MHDDLESEX COUNTY DKMOCRAT PHNT

1884

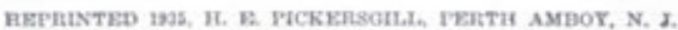

Fig. 5. The title-page of a pamphlet issued to commemorate the vote cast by Thomas Peterson-Mundy in a local Perth Amboy election, March 31, 1870. He thus became the first African-American voter in the United States. (from the Sinclair New Jersey collection in Special Collections and University Archives) 
forbidding the exclusion of any child from a public school because of religion, nationality, or color. The 1881 law resulted in the virtual disappearance of separate black schools in the northern counties, but not in the southern counties where the majority of such schools had been established. The law did not prevent the continued establishment of separate black schools, but rather prohibited the exclusion of blacks from white schools. The petitions of some blacks in mainly southern New Jersey communities for the creation of black schools contributed to the continuation of segregation practices in the southern counties. ${ }^{70}$

Following the 1881 law, blacks in Asbury Park sought a separate school. By 1889 , there were six racially separate schools in Monmouth County. In 1881, Atlantic City established a segregated school for forty-six black children. The geographic division in the state reflected in the establishment of racially integrated or separate schools was also present to a lesser extent in the attitudes of blacks toward these schools. While blacks in a northern community like East Orange thwarted attempts to introduce segregation, blacks in Fair Haven and Long Branch accepted separate schools. In Fair Haven, the advocacy of separate schools by the visiting exCivil War general Clinton B. Fisk, for whom the Tennessee black college was named, persuaded a divided black community meeting to accept a racially separate school. Afro-Americans may also have been motivated to accept or even seek separate schools in South Jersey because of the hostility of whites to integration, fear of mistreatment of their children in racially mixed schools, or a preference for black teachers. ${ }^{71}$

The New Jersey Supreme Court delivered a rebuke to the supporters of racially segregated education in the 1884 Pierce case. Rev. Jeremiah H. Pierce petitioned the Court on June 13,1883, for the admission of his four children to the segregated white schools in Burlington City. Pierce based his case on the New Jersey School Law of 1881 and the 1844 Constitution. The court's decision on February 21, 1884, held that the denial of admission to Pierce's children was in violation of the 1881 school law. Pierce explained his motivation not only in terms of love for his children, but also of love and concern for his race:

I will admit that I think too much of my children to sacrifice them to the diabolical wishes of ungodly and inhuman characters ... But while this is a fact, it is also true as stated in the beginning that I have a general interest in the defence of my race, and had I no children of my own, I would take the same stand against the color line, for with me color is nothing, but quality is a great deal, and cultivation improves the quality of man, beast or vegetation. ${ }^{72}$

The court's decision in favor of Pierce was a landmark in the history of civil rights in New Jersey, but its impact on segregated education was not immediate. Widespread lack of enforcement by public officials allowed the continued establishment of schools exclusively for black students by narrowly interpreting the law to prohibit only the exclusion of children from white schools on the basis of color. Many school districts in southern New 
Jersey practiced segregation in classrooms and teacher assignments until the 1940s. Burlington continued its separate school for blacks until 1948. ${ }^{73}$

Issues of racial integration and segregation were only part of the educational concerns facing black residents of the state. The need to make education relevant to earning a livelihood was a practical one in an era of continued widespread employment discrimination. In response to the national movement for industrial or vocational training during the nineteenth century, the African Education Society of Newark and national black conventions had advocated the establishment of schools which would combine academic and vocational education. In 1886, Walter A. Rice, a clergyman of the African Methodist Episcopal Church, founded the Manual Training and Industrial School for Colored Youth. The school, then known as Ironsides, was moved to Somerville in 1890 and then to Bordentown in 1896, and thereafter was often referred to as the Bordentown School. In order to bolster the school financially, the state took it over in 1894. In 1900, the legislature transferred control of the school to the State Department of Public Instruction. The Bordentown School, like the Tuskegee Institute model established in Alabama by Booker T. Washington, ${ }^{74}$ and other educational institutions throughout the South, provided basic vocational training in carpentry, brick masonry, plumbing, and auto repair which would facilitate employment in New Jersey agriculture and industry for many graduates. Nevertheless, widespread racial discrimination restricted many other graduates to menial employment. Bordentown joined other forms of public schooling for blacks in New Jersey in failing to produce a significant class of managers, entrepreneurs, or skilled workers. ${ }^{75}$

Advocates of vocational education for blacks did not consider incorporating the expanding fields of clerical employment or skilled industrial jobs. After visiting Bordentown in 1913, Booker T. Washington urged the New Jersey Commissioner of Education to stress domestic education courses (despite the growing fields of clerical work for women); farming (despite the increasingly urbanized nature of the state's poor black population); and employment as chauffeurs (despite the limited number of jobs available). Bordentown may have provided adequate training given the intense prejudice against hiring blacks for the more skilled, higher-paying jobs and the limited influence of a still relatively small black population in the state, ${ }^{76}$ but it reinforced the existing social structure, with Afro-Americans on the bottom.

\section{Civil Rights Act of 1884}

The 1880s were a period of significant gains in the area of civil rights legislation in New Jersey, but of only moderate economic and social progress. Following the passage of the 1881 school law and the $1884 \mathrm{New}$ Jersey Supreme Court decision barring racial segregation in the public schools, the legislature passed the state's first major civil rights act in 
the post-Civil War era. The measure guaranteed equal access to public accommodations for all citizens. The law provided payment of damages of $\$ 500$ to aggrieved parties, and a fine of between $\$ 500$ and $\$ 1,000$ or imprisonment for a term between thirty days and one year. Racial discrimination in the selection of jurors was prohibited and carried a fine not exceeding $\$ 5,000$. This stringent antidiscrimination law failed to end discriminatory actions in the state. It was consistently and even openly ignored, particularly where public accommodations were at issue. The act was revised in 1917 with weaker antidiscrimination provisions. While the state enacted the antisegregation school law of 1881, passed civil rights legislation in 1884, and the state Supreme Court rendered the Pierce decision, certain elements and areas of the state ignored these laws and court decisions, making their enforcement uneven and violation widespread. As late as the 1940s, blacks in Newark and other New Jersey municipalities were forced to sit in segregated balconies in theaters. ${ }^{77}$

Against this background of tentative northern commitment to racial equality, the advocates of white supremacy and black subservience regained control of the governments of the southern states by the late 1870s. In United States v. Cruikshank, the Supreme Court made it more difficult to safeguard black voting in the South. In 1883, the Supreme Court declared the Civil Rights Act of 1875 unconstitutional. By the 1890s, the southern states had effectively disenfranchised the Afro-American population and established legal segregation in all public places. Violence against blacks was commonplace. The Republican and Democratic parties had become equally indifferent nationally to the plight of the freedmen. ${ }^{78}$ But for AfroAmericans living in New Jersey and northern states, the laws for racial equality at least existed, even if the will to enforce them was often lacking.

\section{Leadership and Community}

Afro-Americans were without substantial allies after Reconstruction as the Republican party turned away from the race issue toward economic concerns and the Democratic party maintained its traditional bias against racial equality. Many black leaders were attracted by Booker T. Washington's approach, which emphasized the virtues of hard work and thrift while discouraging overt protest against political disenfranchisement and segregation. Some of New Jersey's black leaders, like those of other states, accommodated themselves to the diminished opportunities for securing equality and accepted portions of Washington's philosophy.

James Still of Burlington County, a prominent black practitioner of folk remedies and the older brother of abolitionist William Still, urged blacks to eschew indolence and the vices of city life while following Washingtonian precepts on the benefits of manual labor and the agrarian way of life. However, Still rejected Washington's acceptance of racial segregation in education. ${ }^{79}$ In a similar fashion, Rev. Junius C. Ayler of Princeton, the 
publisher of Trumpet, a weekly Princeton newspaper, called for blacks to "educate, educate, make money, make money." His advocacy of economic development paralleled that of Washington, but he strongly emphasized that slavery's legacy of poverty, rather than the color of Afro-Americans, was the root cause of prejudice. New Jersey's black leaders during this period accepted Washington's philosophy of black self-reliance, but unlike the southern leaders of their race they recognized the value of the vote in achieving equality. A.P. Miller, pastor of St. Mark's African Methodist Episcopal Zion Church in Jersey City, denounced the "internal burdens" of racial indolence while extolling, as Washington did, the virtues of the Protestant ethic. Yet he argued for academic rather than vocational education and rejected Afro-American political subservience to an indifferent Republican party. ${ }^{80}$

New Jersey black leaders often combined elements of Washington's philosophy with the more aggressive call for political and social equality of Washington's chief critic, W.E.B. Du Bois. Other critics opposed to accommodation and weary of futile attempts to break down the nation's color barrier advocated emigration to Africa. The leading proponent of AfroAmerican emigration was a black southerner, Bishop Henry McNeal Turner of the African Methodist Episcopal Church. An important Turner protégé, Bishop R.H. Cain of the New Jersey Conference of the church, believed with his mentor that future generations of Afro-Americans would return to Africa. The 1886 "Report on Education" of the New Jersey Conference contained affectionate references to the "Fatherland" of Africa and the future Christianization of the continent by black missionaries. ${ }^{81}$ At a time of failing American commitment to racial justice, the image of Africa and the prospects of emigration provided hope and solace to many blacks.

When emigration proved impossible or undesirable, the desire to escape the pervasiveness of racial prejudice gave rise to all-black communities within the state. Perhaps the oldest of these was Gouldtown, in Fairfield Township, Cumberland County. The residents claimed descent from Benjamin Gould and his wife, Elizabeth Adams, the granddaughter of John Fenwick, the proprietor of West Jersey from 1671. Five generations of Goulds had lived in the settlement by 1900 along with descendents from another racially mixed family, the Pierces. By 1907, only fifty families remained, as many residents had migrated to New York, Boston, Pittsburgh, and Chicago. ${ }^{82}$

Only ten miles from Gould town was the black settlement of Springtown, Greenwich Township. "Springtowners" were descended from Delaware and Maryland manumitted or escaped slaves. By 1900, emigration had reduced the settlement to forty families. The attractions of urban life had also reduced the population in the predominantly black town of Snowhill, Camden County, which was later called Free Haven and Lawnside. The community originated as a refuge for fugitive slaves and was an important 
station on the Underground Railroad. Whitesboro, Cape May County, was a refuge for Afro-Americans fleeing the antiblack rioting in Wilmington, North Carolina, in 1898. The migration was led by the black ex-Congressman from the state, George $\mathrm{H}$. White. Approximately twenty black families settled there and worked on their own or neighboring farms. These small black settlements represented an attempt to carve an oasis of freedom out of an era of uncertainty and discrimination. ${ }^{83}$

As the nineteenth century closed, black New Jerseyans had made impressive gains since the end of the Civil War. Slavery had been abolished, citizenship rights achieved, and the vote secured. The state's enactment of a civil rights law and school desegration legislation placed the legal system on the side of racial equality. Popular attitudes, however, changed more slowly, making the actual implementation of such legislation and judicial decisions more difficult as significant areas of the state refused to comply. Afro-Americans in New Jersey had a legislature and a court willing to outlaw segregation in public places and schools, whereas in the South, the U.S. Supreme Court and Congress did not.

\section{The Migration, Depression, and War Years}

As the twentieth century began, New Jersey, like some other northern states, had made progress toward racial equality, eliminating racial prohibitions in voting, passing a civil rights law prohibiting racial discrimination in the area of public accommodation, and through laws and state supreme court decisions outlawing the exclusion of blacks from white public schools. Black optimism was further fueled by Theodore Roosevelt's dinner meeting with Booker T. Washington at the White House on October 16, 1901. ${ }^{84}$

Southern criticism of Roosevelt's meeting with Washington curtailed the willingness of his successors to address the national problem of race in a positive way. A native Virginian, Woodrow Wilson had been president of Princeton University and governor of New Jersey before winning the 1912 presidential election. Wilson believed the social gulf which existed between blacks and whites could be bridged only through the gradual elevation of the black masses through education, vocational training, and improved economic opportunities. He thought there was little that he could do in the meantime to ameliorate the race problem: "I say it with shame and humiliation, I have thought about this thing for twenty years and I see no way out." While Wilson was president of Princeton, the university had excluded black applicants. In 1911, Governor-elect Wilson had ignored the request of the Newark Negro Council for a statement of "friendliness" toward the state's black citizens. Soon after his assumption of the Presidency, he allowed two southerners, Secretary of the Treasury William McAdoo and Postmaster General Albert S. Burleson, to introduce racial segregation in federal offices, lunchrooms. and lavatories. In 1914 the Civil Service Commission introduced a new system which required the attachment of 


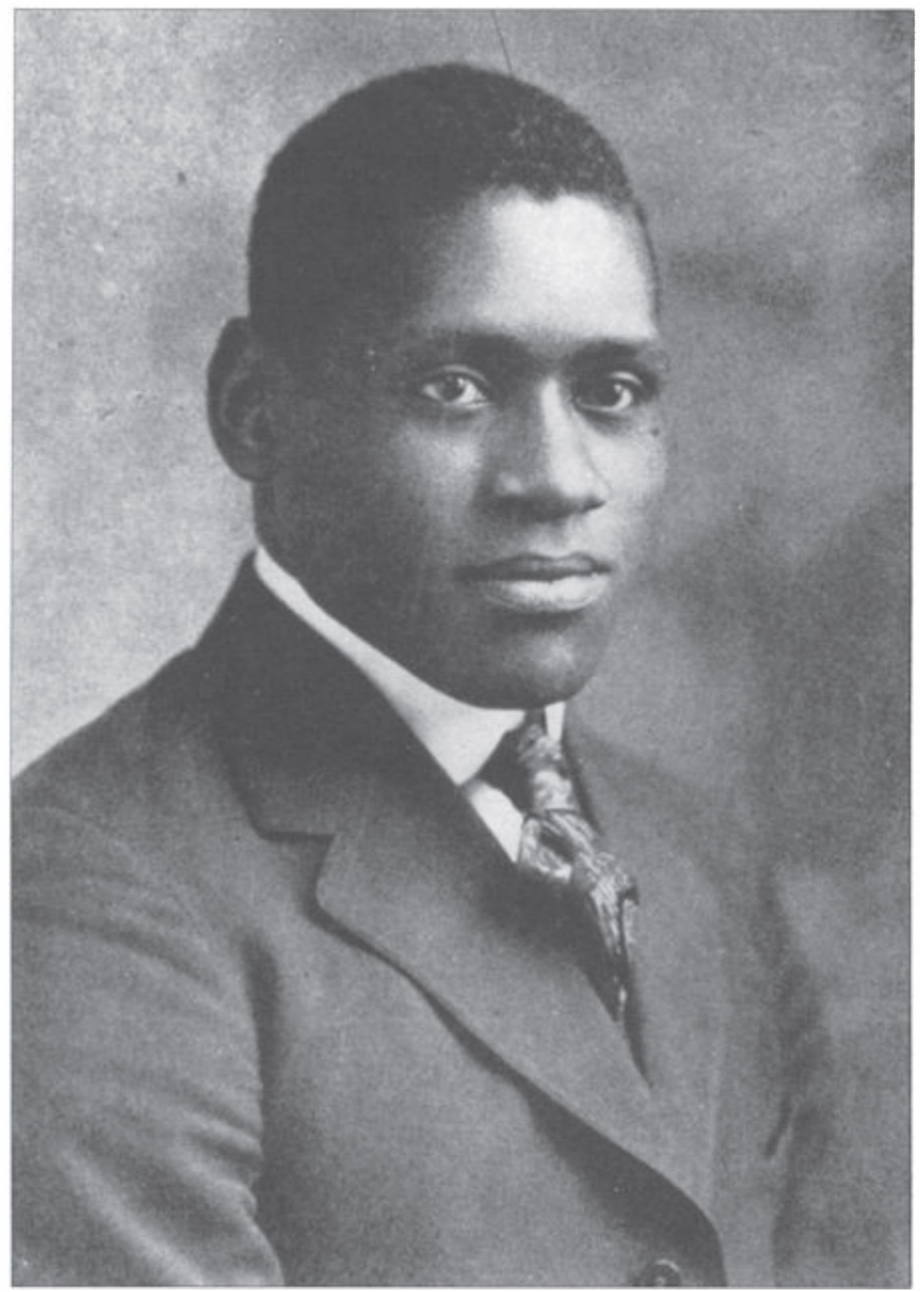

Fig. 6. The senior class picture of Paul Robeson, Rutgers class of 1919. (from Special Collections and University Archives) 
a photograph to all Civil Service examinations. After a sharp verbal clash in late 1914 with militant civil rights advocate Monroe Trotter, Wilson met only occasionally with black leaders, despite their many requests for a meeting. ${ }^{85}$

Woodrow Wilson's reluctance to confront the racial issues of segregation, employment discrimination, lynchings, and black political exclusion coincided with the lack of action of state officials and the growing antiblack attitudes throughout the nation. In 1901 more than 100 blacks were lynched; and the practice, which had been increasing since the $1890 \mathrm{~s}$, continued throughout the first three decades of the twentieth century. Antiblack violence was not restricted to the South. In 1900, antiblack violence erupted in New York City. In 1908, one of the most vicious outbreaks occurred in Springfield, Illinois, the home of Abraham Lincoln. By the time the violence had subsided, two black men had been lynched, six people killed, over fifty wounded, and more than 2,000 blacks had fled the city while hundreds took shelter in the camps of the militia. ${ }^{86}$ Fortunately, New Jersey remained free of this intense level of racial violence during this period. However, the state was not without the potential for violence, since prejudice was still endemic. In 1910 a black man accused of murder was nearly attacked by a white mob while in police custody in Asbury Park. In 1911 the National Association for the Advancement of Colored People fought for the release of a black man unjustly accused of the murder of a white woman in Lakewood. The organization's national publication, Crisis, remarked: "New Jersey seems to lately have changed the phrase 'Look for the criminal' to 'Look for the negro' " 87

Despite the periodic outbreaks of urban violence in the North, AfroAmericans continued to come to northern cities from the South. Political equality, the absence of legal segregation, higher paying jobs, and the hope of better educational opportunities proved to be irresistible lures. The hopes of these migrants may not have corresponded to the reality of northern life, but the reality of the South seemed much harsher.

\section{Migration: $1900-1930$}

The steady stream of southern blacks coming north in the early years of the twenticth century sharply increased during and after World War I, which interrupted the flow of European immigrant laborers to northern industrial cities where they had provided a major source of factory labor. To fill the void, northern employers sent recruiters into the South seeking black workers. While New Jersey's black population had increased by 46.6 percent between 1890 and 1900 (from 47,638 to 69,844), it grew by 132.6 percent (from 89,760 to 208,828) between 1910 and $1930 .{ }^{88}$ As the racial composition of the state changed, new patterns of race relations evolved. Residential segregation of blacks became more pronounced and racial 
ghettoes emerged in New Jersey cities. The war years stimulated the growth of a black industrial labor force which would continue to expand.

Both the racial composition of the state and the everyday life of its black citizens were changing. Newly arrived black migrants found jobs in New Jersey industries at far higher wages than those paid for either agricultural or factory jobs in the South. Wages of Afro-American laborers were lower than those of whites, and the skilled trades remained as off limits to them as they had been at the turn of the century. A 1903 New Jersey labor department survey of eighty-three manufacturing establishments revealed that while blacks and whites were paid equally for the same type of work, blacks were concentrated in the lowest-paying jobs. The hostility of white workers and labor unions to the employment of blacks in other than lowpaying jobs accounts for their partial exclusion from semiskilled and skilled occupations. The use of blacks as "scab" laborers during strikes throughout the nation conditioned white workers to view blacks as potential threats who would work for low wages and possibly cause them loss of employment. At the turn of the century, a survey of twenty-two state labor organizations indicated that only six were open to blacks. ${ }^{89}$ Employers tended to see blacks as unsuited for the more complex tasks. They also feared their white workers would become disruptive if blacks were hired on an equal footing. The prejudices of white workers and of employers restricted the occupational mobility of black residents.

The labor shortage of the war years not only stimulated migration, but also increased the movement of blacks into industrial work, albeit in the lower-paying unskilled jobs. The proportion of blacks in domestic and personal service occupations declined from 55.1 percent in 1910 to 43.3 percent by 1930 , while the percentage of blacks in manufacturing and mechanical industries increased from 18.9 percent to 29.7 percent between 1910 and 1930. By 1920, factory work in Newark had replaced domestic and personal service as the leading source of work for blacks. The occupational diversification of Newark blacks continued throughout the decade, but as in the state as a whole, black workers held mostly menial jobs. Black businesses such as barbershops and restaurants expanded because white businesses usually did not compete for personal services to blacks. AfroAmerican women were still concentrated in domestic service. The State Placement Office found employment for black women primarily as servants, cooks, children's nurses, factory operatives, steam pressers, and waitresses. ${ }^{90}$

Unlike most New Jersey cities, Atlantic City saw its black population increase rapidly before World War I, as that seaside resort was transformed from a small bathing village in 1854 to "America's Playground" by 1900 . Blacks went to Atlantic City seeking service jobs in the booming tourist industry. By the turn of the century, the hotel-recreation labor force had 
become 95 percent black. In 1912 Atlantic City boasted more than 100 hotels and boardinghouses, with twenty-two prominent hotels accommodating over five hundred guests. In 1870, blacks were only 8 percent of the city's population; by 1915 this proportion had risen to 27 percent. In contrast, the black populations of Newark, Trenton, Jersey City, and Elizabeth were only 3 percent or less of the total population in 1915, while Camden possessed a black population of 6.2 percent. ${ }^{91}$ In the 1880 s Atlantic City had attracted blacks as seasonal hotel workers, but as the city grew in popularity as a year-round resort, black workers found annual rather than seasonal employment.

Although variations in population growth often depended on the unique economic characteristics of each New Jersey city, certain common experiences in residential patterns and race relations emerged during this period. As migration expanded, the once-dispersed Afro-American urban populations became increasingly concentrated in racially homogeneous ghettoes throughout the cities. In Atlantic City, for example, blacks in the nineteenth century were fairly well distributed throughout the city, but by 1915 , only 20 percent of blacks had white neighbors. Residential segregation and racial discrimination restricted the housing available to blacks and forced them to pay high rents. To alleviate the pressure of high rents, blacks were forced to take in boarders. The proportion of black households taking in boarders increased from 14 percent in 1880 to 57 percent by 1915 . Household congestion made the maintenance of household stock more difficult and increased the susceptibility of children to infectious diseases. Black infant mortality rates greatly exceeded those of whites during these years. In 1910, 24.9 percent of black children died before the age of one as compared to 7.8 percent of white. ${ }^{92}$

Between the wars Afro-Americans in northern New Jersey towns increasingly faced residential segregation similar to that of Atlantic City. In Newark between 1900 and World War I, blacks were dispersed throughout white neighborhoods and the city had a superficial atmosphere of racial tolerance. Working-class whites and blacks often lived on the same streets, shopped in the same stores, and sent their children to the same schools. After World War I black migration increased and property owners and real estate interests tricd to restrict black settlement to the old working-class districts of New Jersey cities. By 1930 nearly half of black Newarkers lived in the Third Ward and by 1940 almost two-thirds resided there. Newark commercial zoning ordinances between 1920 and 1930 tended to retard residential housing in much of the central city where many blacks lived. Nearly all of the densely populated Third Ward was zoned as a business district despite the commercial decline of the area during the early twentieth century. Residential construction was effectively blocked and the inner city remained underhoused during the $1920 \mathrm{~s}^{\text {and } 1930 \mathrm{~s} .}{ }^{93}$ 
In the Third Ward, fewer than ten houses were built in the 1920s, and more than half the housing was unfit for use or in need of major repair, according to a Department of Health survey. Correspondingly, the tuberculosis rate for black Newarkers was twice that of whites. Pneumonia and tuberculosis were the principal causes of death among blacks. The Third Ward became notorious for its disease and death rates, ranking first in epidemic meningitis, erysipelas, influenza, and tuberculosis. Dr. Craster of the Department of Health said that old dilapidated buildings long closed as undesirable for habitation were reopened and rented to blacks, often lacking, or having inadequate, kitchen ranges, lavatories, baths. amd toilets. A majority of these places were unheated. Policies keeping blacks from visiting many hospitals or medical personnel contributed to the poor health status. The ability of whites to escape the poor housing and congestion of the inner city for newer accommodations in the less-densely populated areas of the city or suburbs also accounts for the great racial disparity in disease and mortality rates. ${ }^{94}$

World War I and postwar migration of blacks shattered the old pattern of race relations and the illusion of group progress. The increasing social problems associated with black settlement and ghettoization stigmatized Afro-Americans as untutored, powerless, and unassimilable. Accompanying the pattern of residential segregation was an increasing social segregation in New Jersey cities. In Atlantic City, blacks were barred from restaurants, amusements, piers, and various stores. They were admitted to hotels only as servants and could use only one section of the beach, at Missouri Avenue. In the hospitals and clinics, they were segregated. Similarly in Camden, municipal authorities had designated certain parks and other recreational areas for the sole use of blacks. As in Atlantic City, separate YMCA and YWCA facilities existed. In Newark, blacks were denied service in many business establishments. In most pre-World War II moviehouses in Newark, from Loew's State and the National to the smaller neighborhood theaters, to even smaller picture shows like the Ritz and the Savoy, blacks were segregated from whites. The Salvation Army, Boy Scouts, and Girl Scouts all accepted this traditional pattern of segregation. In the South Jersey towns of Camden and Atlantic City, racially segregated schools had been established by the turn of the century. By 1930, Atlantic City had four separate black schools. The physical ghetto had engendered an institutional ghetto which the growing number of black professionals, morticians, teachers, and small businessmen, migrating between 1900 and 1940 , would serve..$^{.5}$

The humiliation blacks endured during the early twentieth century was not reserved for recent southern immigrants. Paul Robeson (1898-1976) found his initial reception at Rutgers tinged with racial prejudice. Only two blacks had attended the university since its founding in 1766 . He was barred 
from traveling with the college glee club and was the target of physical abuse by his football teammates. However, Robeson rose above the racial abuse to achieve a distinguished academic and athletic career at Rutgers. In his junior year, 1918, he was elected to Phi Beta Kappa and in 1917 and 1918 to the All-American football team. Despite the presence of this outstanding student-athlete, his university barred Robeson from a game with Washington and Lee University of Virginia when that institution objected to its team playing against a black man. By the time Robeson graduated in 1919, the student body at Rutgers recognized his contribution to the school and his outstanding character in the student yearbook, The Scarlet Letter. Robeson went on to Columbia University Law School and an international career as a singer, actor, and activist. ${ }^{96}$

There were lesser-known Afro-Americans who made significant contributions to the nation and the state during the war years who also had to wait to receive recognition at home. National Guard units from Massachusetts, Ohio, Maryland, New Jersey, and the District of Columbia composed the 372 nd black infantry regiment. Colonel Tupes, the white commander of the regiment, observed that black junior officers displayed conspicuous courage in battle but were inclined to protest race distinctions. Despite discrimination within the army, black soldiers displayed valor on the battlefield. On May 14, 1918, two soldiers of the black 369th infantry regiment, while on guard duty at an American outpost on the front lines in France, successfully fought off a German raiding party of twenty soldiers. Although wounded and outnumbered, these men held their ground. Two members of the 369th, Privates Henry Johnson of Albany and Neeham Roberts of 'Trenton, became the first American soldiers to earn the French Croix de Guerre. This primarily New York unit was cited for bravery eleven times. Yet, upon return from the war, Corporals Lewis Jackson and Edward Buckley were refused service at a soda fountain outside Camp Dix in South Jersey. Black contributions to the war did not alter the atmosphere of racial prejudice encountered by many Afro-American newcomers to the state in the $1920 \mathrm{~s}^{97}$

World War I stimulated the growth of patriotism and a concern for preventing future wars, but the period also saw the revival of the Ku Klux Klan with a new anti-immigrant, anti-Catholic, and anti-Semitic bias added to their traditional antiblack prejudice. Throughout the 1920 s, the Klan expanded from a southern regional organization to a national organization with approximately five million members and chapters in the North, West, and the mid-West. This secret organization spread into New Jersey in early 1921 from New York and Pennsylvania. Klan leaders believed that New Jersey, with its large European immigrant population, influx of southern blacks, and religiously diverse population of Catholics and Jews, would be a state ripe for Klan propaganda and the recruitment of individuals opposed to these groups. Klan strongholds existed in Camden, Trenton, Paterson, 
Jersey City, and Hoboken. Klan locals were established in smaller, largely Protestant, communities throughout the state (e.g., Pleasantville, Plainfield, Long Branch, and Asbury Park). Although the secret order never achieved political power statewide, it did dominate politics in some smaller towns. Many New Jerseyans opposed the Klan and this opposition burst forth in two Perth Amboy anti-Klan riots in the summer of 1923, when Klan rallies were disrupted and their participants beaten and run out of town. Cars were overturned and burned and Klan recruiters attacked, despite the rescue attempts of city and state police. Poles, Russians, Italians, Jews, and blacks, some coming from as far as Atlantic City and Newark, apparently found the Klan speaker's assertion that they were unassimilable and "unworthy of American nationality" too offensive to ignore. The Perth Amboy riots marked the end of serious Klan penetration of New Jersey. ${ }^{98}$

\section{Depression Years: $1930-1940$}

By early 1932, the depression which had begun in 1929 was the most severe in the nation's history. In New Jersey an estimated 400,000 were out of work. A third of the state's total population were either unemployed or affected by the depression by 1934 . The depression brought tremendous hardships for all Americans, but for blacks it was a double tragedy. Racially stigmatized and concentrated in the lowest-paying occupations, they were the most vulnerable to unemployment. As early as April 1930, New Jersey black unemployment was almost twice as high as that of the whole state and nearly three times as high as that of the native white population. A survey of black families for that year found nearly 30 percent of the employable work force unable to find work. The old adage of "last hired, first fired" appeared applicable to blacks. ${ }^{99}$

The disproportionately high black unemployment during the depression years was compounded by the discriminatory policies of most trade unions and companies in the state. A 1932 survey by the New Jersey Conference of Social Work revealed that 57 percent of employers excluded qualified black workers from the better jobs and denied them opportunities available to white workers. Blacks comprised 5 percent of the state's population but only 1.5 percent of the membership in forty-one state labor organizations. Union discrimination in a city like Newark made it impossible for blacks to secure training through apprenticeships. Union influence in the vocational school system made it difficult for blacks to obtain training, through these institutions. A vicious cycle existed: blacks could not get jobs because they lacked training, but they could not get training because they were excluded from the jobs. The prospects for black professionals, usually limited to serving the black community, worsened in the depression as unemployment rates rose and income rapidly diminished. The principal of the Newark State Normal School noted the limited opportunities for black teachers in 1932: "There are only a few cities in the state that employ 
Negroes to any extent. The city of Newark has employed no additional Negro teachers for a number of years, although the majority of Negroes come from the state." 100

These circumstances forced a disproportionate number of AfroAmericans to seek public assistance. By 1936 blacks accounted for 23.5 percent of the state's relief population, although they were only 5 percent of the population. Many private social agencies either denied aid or limited assistance to blacks. The Salvation Army and the Goodwill Mission in Newark refused to lodge destitute blacks. During the worst period of the depression, Newark did not have a residence for homeless black women and homeless black men had access only to cramped and inadequate municipal facilities. The Newark Female Charitable Society, the Social Service Bureau, the Church Mission of Help, the Travelers' Aid Society, and the New Jersey Urban League helped needy blacks, but these organizations had inadequate financial resources. A belief prevailed that too liberal an assistance policy would encourage massive southern black migration to New Jersey and drain limited resources. In reality, nearly 90 percent of both black and white relief families had entered the state before 1932 . Nearly half the transient homeless blacks were from northern states, and 93.2 percent came to the state seeking work, not relief. ${ }^{101}$

Housing shortages, high disease rates, and social discrimination continued to plague New Jersey's black residents through World War II. Despite the pressing need for black health care professionals, for example, only five black physicians were known to be on hospital staffs in the early years of the depression. One of the few bright spots was that New Jersey's black population had reduced its illiteracy from 30.5 per thousand in 1880 to 5.1 per thousand by 1930 . Black social, fraternal, religious, and civic organizations worked toward the betterment of their communities. The National Association for the Advancement of Colored People had nineteen branches in New Jersey campaigning against racial segregation and discrimination. The New Jersey State Federation of Colored Women's Clubs, which had seventy-two affiliated bodies in 1930, provided scholarships for high school graduates. The Federation of Colored Organizations of New Jersey had been organized in 1915 to encourage racial unity and civic pride. It focused on political equality and stimulating black business opportunities. 'There were numerous other racial organizations laboring to achieve similar goals in the state. ${ }^{102}$

Black churches were a source of strength in easing the adaptation of black migrants to city life and later in lessening the burden of the depression. By the mid-1920s, black churches comprised 11.2 percent of the total number of churches in the state and provided recreational and charitable assistance programs. In addition to the major black denominations, the efforts of such nondenominational leaders as Father Divine helped to lessen the impact of the depression on blacks in the northern states. 
This self-styled God and leader of the Kingdom of Peace movement established three missions and the 250-room Divine Riviera Hotel in Newark which provided cheap lodgings and meals, as well as the Fairmont Hotel in Jersey City. ${ }^{103}$

On the political scene Afro-Americans sought the election of members of their race to governmental office as the migration expanded the black electorate in the state. In 1921, a Republican from Orange, Walter G. Alexander, became the first black assemblyman in the state legislature. In the 1930s, high unemployment and declining wages stimulated a major political realignment of black voting patterns. Franklin D. Roosevelt, in 1932, made significant inroads among traditionally black Republican voters. President Hoover's inability to cope with the depression cost him black support. By 1936, black voters, like other citizens, viewed President Roosevelt's economic reforms and relief agency efforts positively. Roosevelt's image among blacks was enhanced by the liberal views of his wife and by his appointment of blacks as cabinet officers. New Jersey's election of its first black Democrat, Guy Moorhead of Newark, as state assemblyman was indicative of this national realignment. ${ }^{104}$

The political awareness of the state's Afro-American population was not limited to the sphere of electoral politics. Across the nation during the 1930 s, black protests and boycotts erupted against large stores conducting business in black areas but refusing to hire black managers and clerks. The Newark unit of the National Negro Congress inititated a "Don't-BuyWhere-You-Cannot-Work" campaign as blacks had done in New York, Chicago, and other northern cities. ${ }^{105}$

The increase in black protests and officeholders and the swing to the Democratic party did not significantly alter blacks' social and economic status, but it did mark the beginning of more vigorous use of politics and protest tactics to achieve racial justice.

\section{World War II}

As war threatened after 1939, blacks, warned that Afro-Americans forced to observe the "color line" at home "may draw the COLOR LINE in 1940, or whenever THAT WAR does come." The Pittsburgh Courier launched a double V campaign among blacks: "Victory Abroad and Victory [Against Discrimination] at Home." Fearful that blacks would not obtain jobs in the growing defense industry, insulted by the continuing segregation in civilian and military life, and angered by the persistence of lynching and political disenfranchisement in the United States, blacks mobilized to pressure the federal government for redress. In January 1941, A. Philip Randolph, president of the Brotherhood of Sleeping Car Porters, called for a march of 50,000 to 100,000 blacks on the nation's capital to force the government to correct these injustices. President Roosevelt, fearful of disunity at home and possible damage to America's democratic image, issued 
Executive Order 8802 on June 25, 1941, banning racial discrimination in defense employment. ${ }^{106}$

After Pearl Harbor, blacks closed ranks with the rest of the nation and supported the war on the battlefield and the homefront. A few small black nationalist religious sects opposed the war. In January 1943, members of the House of Israel were arrested when they refused to be drafted. In February 1943 the Federal Bureau of Investigation arrested three black conscientious objectors belonging to the Allah Temple of Islam in Newark. Most blacks, however, deferred their legitimate grievances and either enlisted or were drafted. Black state militia units organized after the end of World War I (Companies A, B, C, D), which made up the First Battalion of the 372nd Infantry of the New Jersey National Guard, were ordered into federal service. A group of twenty-three black officers and 350 enlisted men were ordered into federal service with the New Jersey National Guard. The armed services inducted 24,871 New Jersey black men by the end of the war. The Women's Army Corps enrolled 89 black women from the state. Afro-American men and women from New Jersey served their country with distinction, earning such medals as the Bronze Star, the Purple Heart, the Legion of Merit, and the Oak Leaf Cluster. ${ }^{107}$

On the homefront, blacks also contributed to the war effort. In the state division of the American Red Cross were some 2,796 black volunteers working as nurses' aides, first aiders, drivers, and in blood donor programs, and providing other necessary support services. Nearly 6,000 black volunteers participated in the state's Office of Civilian Defense activities, which were divided into the Civil Protection Patrol and Community War Services programs.

Most important for blacks, the most hard-hit victims of the depression, the war stimulated American industry and reemployment opportunities. Roosevelt's executive order pierced the color barrier in numerous industries despite widespread violation in the South and to a lesser degree in the North. The War Manpower Commission found that nonwhite (i.e., mainly black) employment in the largest industry groups in New Jersey constituted 9 percent $(55,776)$ of the total number of employees. ${ }^{108}$

As a result of a world war against racist oppression, Afro-American New Jerseyans made significant occupational progress at home.

\section{The Post-World War II Years}

World War II ended with America victorious and the racist principles of Aryan supremacy rejected. The ideological victory for those advocating racial equality made overt expressions of racism less respectable in the postwar era and gave impetus to blacks' struggles for civil rights. During the war, blacks in America pushed vigorously for civil rights, an equal role in an integrated military, and equal employment opportunities in defense 


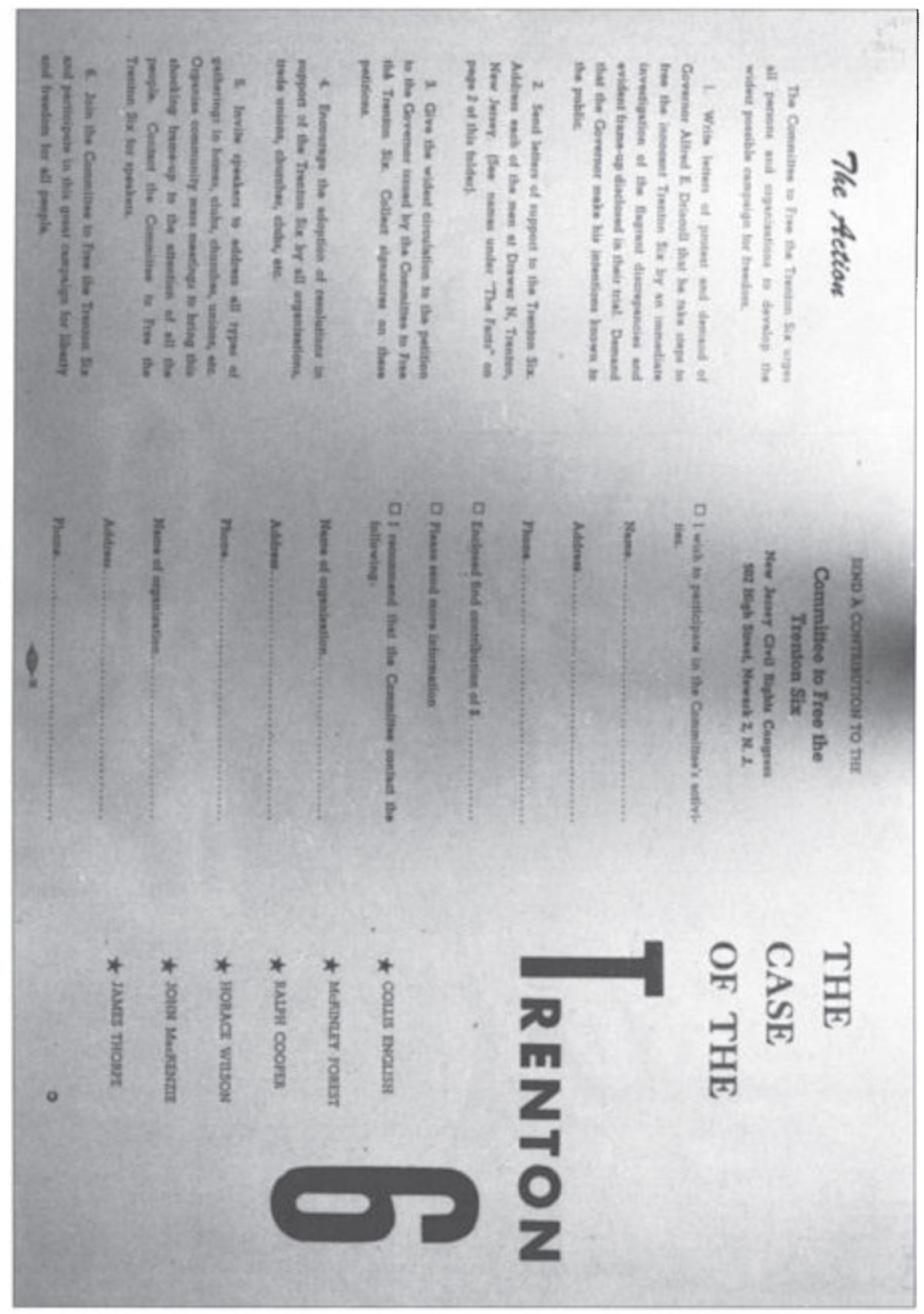

Fig. 7. A 1948 broadside issued by the Committee to free the Trenton Six. An early effort to draw public attention to a controversial murder case. (from broadsides collection in Special Collections and University Archives) 
industries. World War II ushered in both the decline in respectability of racist ideologies and the beginnings of the modern civil rights movement. ${ }^{109}$

After 1945, increased pressure for racial equality by civil rights organizations like the NAACP made the federal government more sensitive and responsive to an expanding black electorate's quest for racial justice. President Harry S Truman helped shape the climate in which the status of black Americans could be improved; in 1946, he appointed an interracial committee of distinguished Americans to investigate civil rights and make recommendations for improvement. Their report, To Secure These Rights, condemned the denial of civil rights and called for the elimination of segregation and the strengthening of civil rights. Truman issued an executive order barring discrimination based upon race, color, or religion within the federal government. Another presidentially appointed committee made recommendations in its 1949 report, Freedom to Serve, to stimulate the integration of the armed forces and in that year the army opened all jobs to qualified personnel without regard to race or color, and eliminated racial quotas. The navy and air force adopted similar policies. These steps led to the development of integrated military units and America's participation in the Korean War with racially integrated armed forces. Between May and August 1951, the number of troops in integrated units in Korea increased from 9 percent to 30 percent of all troops in the field. ${ }^{110}$

Changes in race relations practices in the nation's capital fittingly symbolized the country's racial progress. Following World War II, the larger hotels in Washington, D.C., began accepting black guests and most other hotels rescinded their racially exclusionist policies by 1956 . Movie theaters and public recreational facilities like parks, playgrounds, and swimming pools followed suit. In 1953, Washington restaurants ended their segregationist policies when the Supreme Court upheld an 1872 Washington, D.C., Reconstruction law which required business establishments to serve "all" respectably behaved persons. The Supreme Court continued the assault on racial inequality in 1954 with Brown v. Board of Education, declaring separate but equal schools "inherently unequal" and unconstitutional because the black paintiffs were "deprived of the equal protection of the laws guaranteed by the Fourteenth Amendment." 111

In 1955, the Interstate Commerce Commission ruled that racial segregation on interstate trains, buses, and their waiting rooms must end by 1956 . After violent confrontations and sit-ins in the South in the early $1960 \mathrm{~s}$, and Martin Luther King's 1963 March on Washington, the U.S. Congress finally passed the 1964 Civil Rights Bill and the 1965 Voting Rights Bill. These important pieces of legislation along with federal court decisions constituted the legal basis for assault on de jure segregation and the creation of a significant black electorate in the South. ${ }^{112}$

The thrust of national legislation and judicial decisions primarily affected racial inequalities in the South, but in the northern states blacks 
began to press for greater participation in Republican and Democratic parties and politics. In New Jersey, as on the national level, the antiracist legacy of the World War II campaign against Fascism bolstered efforts to bring about 1945 and 1949 laws against discrimination as well as the antidiscrimination provisions of the 1947 state constitution. Afro-American residents of the state as well as those throughout the nation learned that the mere passage of laws and court decisions would not bring about racial equality. ${ }^{13}$ Economic parity would prove a long-elusive precondition for full social acceptance.

\section{New Jersey Constitution}

In the years immediately after World War II, New Jersey became a leader in eliminating the legal foundation of racial segregation and discrimination. The state of New York in 1945 enacted a Fair Employment Practices law which expanded employment opportunities for all minority groups. The New Jersey legislature followed this lead in April 1945 with the passage of the Act Against Discrimination, which prohibited racial discrimination in employment and established a Division Against Discrimination in the Department of Education. The law created the first state agency in New Jersey's history for the eradication of racial discrimination. ${ }^{14}$ Two years later, the state became one of the first to make racial segregation and discrimination a violation of its constitution.

Driving forces behind the antidiscrimination clauses of the new state constitution were the mounting pressure of civil rights organizations and the commitment of a progressive governor to racial equality. In 1945, Alfred E. Driscoll, then the Republican candidate for governor, addressed a meeting of the New Jersey NAACP. He called for "full citizenship" for all citizens and the necessity for the state to remove "all forms of discrimination based upon race, creed, color or national origin." Driscoll's liberalism was derived from that of his parents. His mother had been a long-time member of the Camden County NAACP. Mrs. Driscoll was a founder and active member of the Camden County Intercultural Group, whose membership included all races and religions. Driscoll's personal commitment to a state constitution and laws enshrining the principles of legal equality succeeded because of the widespread support in the black community for these measures. The state NAACP released a study a few months before the constitutional convention met in New Brunswick in the summer of 1947, revealing illegal school segregation practices in nearly all of the eighteen counties investigated. Racially separate school systems still existed in Atlantic, Camden, Cumberland, and Cape May counties. Black and white students were taught in separate classrooms in Burlington and Bergen counties. ${ }^{115}$

Black testimony before the constitutional convention and appeals sent to the convention convinced politicians and civic leaders of the urgency of 
including antidiscrimination provisions in the new framework for state government. Fred Martin of Jersey City, representing the State Council of the NAACP, reminded convention delegates of the inconsistency in America's asserting its role as democratic example to the world while not having a democratic form of government at home. Former Assemblyman J. Mercer Burrell, a lawyer for the Essex County Colored Republican Council, asserted the necessity of having domestic realities coincide with the ideals of American foreign policy. A resolution from the New Jersey State Federation of Colored Women's Clubs urged the adoption of a civil rights provision modeled after the one in the New York State Bill of Rights. The new constitution ratified by the voters on November 4, 1947, contained the following antidiscrimination section (Article I, paragraph 5): "No person shall be denied the enjoyment of any civil or military right, nor be discriminated against in the exercise of any civil or military right, nor be segregated in the militia or in the public schools, because of religious principles, race, color, ancestry or national origin." 116

Despite these antidiscrimination provisions, the New Jersey National Guard established racially segregated units in 1947 and 1948, claiming that the state would lose federal recognition and federal funds if the state units were integrated. At a time when the federal government retained segregated units in the armed forces, New Jersey had provided the legal foundation for the integration of the state militia. Governor Driscoll directed that any order of the Department of the Army against racially mixed units be ignored as incompatible with the state constitution. In February 1948, the Secretary of the Army, Kenneth C. Royall, avoided a confrontation by stating that nonsegregated units of the New Jersey National Guard would not be denied federal recognition. After a State Department of Education survey revealed the continuation of segregation and inequality, Governor Driscoll issued a directive ordering all conditions which violated the state constitution provisions on full equality to be corrected as of September 1, 1948; school districts which did not comply would be denied state funds. The state judicial system continued the assault on discrimination. In 1948, the New Jersey Superior Court held in State v. Roseclief Realty Company that racial exclusion in swimming pools was prohibited by the 1935 state civil rights act. Again, in 1949 the New Jersey Superior Court ruled in Seawell v. MacWithey that the City of East Orange acted illegally in excluding black veterans from public housing projects in violation of federal and state laws. ${ }^{117}$

In 1949 the state legislature joined the executive and judicial branches of government in the attack on discrimination when Assemblywoman Grace Freeman introduced a comprehensive civil rights bill. The bill prohibited discrimination in hotels, theaters, restaurants, sports arenas, and all public places. It provided for the establishment of regional and community commissions to investigate complaints of bias and to use conciliation 
and persuasion to eradicate discrimination. If a settlement could not be reached, the commissions had the right to resort to the courts to enforce civil rights, with penalties of fines or imprisonment. Two members of the NAACP, Herbert H. Tate and J. Mercer Burrell, helped write the law. Driscoll signed the bill in 1949, despite the opposition of hotel owners, stating the majority of New Jersey citizens would "not oppose this humanitarian program." 118

The regulation and enforcement of the Freeman Act, like the 1945 Act Against Discrimination, was assigned to the Department of Education's Division Against Discrimination (DAD). Working with the DAD was a State Council Against Discrimination which was given the responsibility of creating councils to work on problems of minority groups at the grass-roots level. Because funds were limited, only eight such bodies were established. Robert Clothier, president of Rutgers University, was the first chairman of the State Council. Thomas Bell, a black physician, was appointed to the State Council. On his death he was succeeded by Herbert H. Tate, a black lawyer and member of the Newark Board of Education. The efforts of the DAD and State Council for civil rights were enhanced by the NAACP through its national leaders and the determination of such local citizens as Dorland Henderson, Ulysses Wiggins, Margaret Caution, and Clifford Moore. Through the efforts of DAD Commissioner Joseph L. Bustard, Assistant Director Harold Lett, and Educational Director Myra Blakeslee, examples of racial bias were brought into the open. The staff of the DAD also launched a public educational program. From 1949 through 1951, DAD members addressed 377 separate groups and delivered speeches in seventy municipalities and twenty counties. The agency published a news bulletin, Division Review, which contained important information on civil rights municipal commissions. One area of racial progress during this period was the increase in the employment of black teachers in the state from 479 in $1945-46$ to 582 in $1952 .{ }^{119}$

\section{The Trenton Six}

New Jersey's Afro-American population secured the legal and constitutional basis for equality, at least in terms of state law, in the immediate postwar period. The case of six black men accused of the murder of a white, seventy-two year old, William Horner, in 'Trenton on January 27, 1948, put New Jersey's commitment to a severe test during the next five years. This case became an important cause in liberal and civil rights circles for it raised questions concerning the treatment of black suspects in police custody and their ability to obtain a fair trial: "It brought to wide public attention the fragile legal rights of poor, uneducated blacks in the cities of New Jersey." The defense of the "Trenton Six" revealed the deep division between such civil right groups as the NAACP and the communist-organized Civil Rights Congress which supported them. ${ }^{120}$ The conflict mirrored the historic 
contest between the two groups for the support of the black community and the increasing domestic fears of communism in America during the Cold War.

The first trial found all six defendents guilty. On appeal, the New Jersey Supreme Court reversed the first verdict because the trial judge had improperly sentenced the six to death and doubt had been cast on the confessions of five of the defendants. The second trial, in 1951, ended in a mistrial after the Mercer County prosecutor became seriously ill. By the end of the fifteen-week third trial in 1951, the case had become a popular cause among civil rights organizations, labor unions, and radical groups. Some supporters of the six black men charged the Civil Rights Congress with using the case to discredit the American legal system and with giving secondary importance to winning acquittal for defendants. Fearing that the association of communists with the defense would make it more difficult for the accused to obtain a fair trial, moderate civil rights organizations pressured the Civil Rights Congress to remove their lawyers from the second case. The third trial ended with four of the six found not guilty. The guilty verdict against Ralph Cooper and Collis English was reversed by the New Jersey Supreme Court. English died in prison awaiting the fourth trial and Cooper pleaded no defense and was sentenced from six to ten years in prison. Cooper was paroled in November 1955, nearly seven years after his first trial. ${ }^{121}$ The trial of the "Trenton Six" foreshadowed the urban unrest of the 1960s when the fairness of the judicial system, law enforcement, and the economic system came under increasing criticism by urban blacks separated from the American dream by the geography of de facto segregation and by lower standards of living.

\section{Post-World War II Urbanization}

During and just following the war years, northern cities saw the emergence of new politics more sympathetic to black political aspirations and stimulated by a large northward migration of southern blacks. Between 1940 and 1950, almost 1,244,700 blacks moved into northern cities. In the succeeding decade, the number approximated 1,457,000. By 1960, the Afro-American population was 73 percent urban compared to 73 percent rural in 1910. This second great wave of black migration completed the transformation of Afro-Americans to a predominantly urban population. New Jersey reflected this regional redistribution as the state's black population increased 239.9 percent from 226,973 to 770,292 between 1940 and 1970. Most newcomers settled in northern New Jersey cities. ${ }^{122}$

The large increase in the urban black population paved the way for expanded Afro-American political involvement and civic participation. The transformation of Newark from a city 11 percent black to one 35 percent black between 1940 and 1960 coincided with heightened efforts of the Newark NAACP to remove employment barriers faced by black 


\section{Crusade for Equality and Protest Meeting}

The thundersous demands for equality by colored peoples are coming from every corner of the globe, especially from the South. These thunderous demands place our Crusade for political equality high on the order of the day for everyone. Now is the time for Negro voters in Essex County to gain equality of treatment from both major political parties.

Back our demands of the Democrats:

- Equal representation on committees.

- Equal voice in the selection of candidates.

- Equality of jobs in all categories.

- Greater Negro representation for elective office from County Committee to Congress.

\section{Sunday, September 20th 3:30 P. M.}

\section{ST. JAMES A. M. E. CHURCH} REV. BLAKE, Pastor

High and Court Streets, Newark, N. J.

\section{Guest Speakers:}

- REVEREND LUTHER E. LUTHER CUNNINGHAM

Pastor, St. Paul's Baptist Church, Philadelphia

Member, Civil Service Commission, Philadelphia

- ROBERT RIX

President Local 49.A

United Packinghouse Workers of America, AFL-CIO

- OTIS W. KING

Candidate for Sheritt, Essex County

\section{Music by Jimmy Watkins and His Unity Gospel Singers}

\section{Rally Committee}

Dr. John W. Axelander, Chairmany Leo Branham, Mrs. Mollie Brown, Bruce Gibson, Daniel Horton, Charles Matthews, Daniel Tucker, Reverend Edgar Thomas, Emest Thompson, Jimmy Watkins and James Weeks.

Sponsored by Essex County Negro Democratic Committee for Recognition

Fig. 8. Flyer advertising political rally in Newark, N.J. in 1959. (from Ernest Thompson papers in Special Collections and University Archives) 
teachers and administrators. Grace Fenderson, the NAACP chief strategist and coordinator in the 1940s and 1950s, was aided by branch presidents Harry Hazelwood, Thomas Pettigrew, and Carlton B. Norris. The Urban League concentrated its efforts on increasing the number of jobs available to blacks and improving social services for the black community, especially within welfare agencies. A combination of philosophy and expediency led both the NAACP and Urban League to adopt a low-key approach to avoid open and bitter controversies. More militant groups like the Baptist Ministers' Conference regularly criticized the slow rate of progress for Newark's blacks. Militant activists in various left-wing groups like the New Jersey Civil Rights Congress, Negro Labor Council, and Negro Labor Vanguard forcefully criticized the lack of significant racial change. Timothy J. Still, a neighborhood leader and resident of the William P. Hayes housing project, became a spokesman for the needs of public housing tenants. ${ }^{123}$

The increasing black population in New Jersey cities after World War II led to a gradual expansion in the number of black officeholders. By 1945, most Democratic district leaders in Newark's predominantly black Third Ward were Afro-Americans. In 1947, James Curtis, a black Republican lawyer, won election to the state assembly. Edward T. Bowser, Sr., a suburban black Republican, won an assembly seat in 1951. Three years later, Rev. Raphaeus P. Means became the first black elected to the Essex County Board of Freeholders. In 1957, Madeline A. Williams, a NAACP leader from East Orange and a Democrat, won an assembly seat. On the municipal level, Rev. William P. Hayes had been appointed chairman of the Newark Housing Authority in 1947. During the mid-1940s through the early 1950s, William R. Jackson, Herbert Tate, and Mary Burch served on the Newark Board of Education. By 1952, George Jones was appointed manager of the Felix Fund housing project and other blacks held some lower-level jobs at city hall. ${ }^{124}$

Despite these political gains, blacks in Newark as in other cities found themselves only marginally included in local political processes. With a view to changing the situation, black residents of Newark supported the change in Newark's city government from commission form to mayor-council structure, since the old form had left them without a representative on the commission because commissioners were elected at large rather than by districts. In the first election for the mayor-council government in 1954, Leo Carlin was elected mayor and a black newspaperman, Irvine I. Turner, was elected from the newly created Central Ward. Turner became the most powerful black politician in the city, controlling nearly all of the patronage given to blacks. Turner's source of power derived from his ties to the Newark Housing Authority, a large provider of jobs in the city and the main landlord for the city's poor. Even with this expanded political role and antidiscrimination laws, residential segregation and significant differences between black and white incomes persisted. In Newark, three public 
housing projects remained 90 percent white and four were 90 percent black. Social and economic progress lagged behind the modest political advancements and more important, black political gains were unable to produce any substantial effect on the income and employment patterns for many citics where a predominantly urbanized black population now lived. Newark, for example, lost 250 manufacturers between 1950 and $1960^{125}$ —a loss that the city increasingly in need of tax revenue, and recent black migrants urgently in need of jobs, could ill afford.

\section{Urban Unrest}

Foreshadowing the national eruption of racial unrest in cities in the late 1960s over unemployment and lack of political influence, a campaign to integrate the schools in Englewood, New Jersey, was initiated in May 1963 as civil rights activities spread across northern states. Thirty black students, with the support of most of the black community, began a sit-in at Englewood's predominantly white Cleveland Elementary School. Employing the tactics of the southern civil rights movement, blacks protested racial inequities with a boycott of downtown stores, a sit-in at the school superintendent's office, and demonstrations at the governor's Trenton office. ${ }^{26}$ 'These incidents marked the transition from the more conservative legalistic and persuasive tactics of earlier decades toward a more militant and activist strategy. Spontaneous racial rioting in Los Angeles, New York, Chicago, Atlanta, Nashville, Houston, and in New Jersey cities like Newark and Plainfield in 1967 reflected the frustrations of urban blacks in a decade of "rising expectations."

The underlying causes of racial unrest were the depressed social and economic conditions in the nation's inner cities. Despite continuing economic growth and declining unemployment rates in the 1960s, the unemployment rate for blacks in 1967 was more than double that for whites. In 1966, approximately 11.6 percent of the nation's whites and 40.6 percent of nonwhites were below the poverty level. In one study of low-income neighborhoods, the subemployment rate (unemployment rate plus underemployment rate) was nearly 33 percent or 8.8 times greater than the overall unemployment rate for all American workers. It is not surprising that a disproportionate number of rioters came from the ranks of the unemployed. In Newark 30 percent of the self-reported rioters were unemployed and 50 percent of those employed were in low-income unskilled jobs. ${ }^{127}$ The disturbances of this era had a racial character, but they also represented the discontent of America's urban poor.

Feelings of political powerlessness intensified feelings of alienation from municipal governments. Prior to the 1967 riot in Newark, Mayor Hugh Addonizio proposed a white high school graduate for the secretary of the Board of Education over the city's black budget director who had a master's degree in accounting. Pointing also to the expansion of the site for the 
medical school, which would displace black residents and dilute black political influence, many black citizens believed that the city administration remained insensitive to their aspirations. Blacks were also underrepresented in other New Jersey cities. In six northern New Jersey communities with sizable black populations and a total of fifty councilmen, only six were black. Black students comprised half of the school population in six school districts, but of a total of forty-two members on boards of education, only seven were black. ${ }^{128}$

Against the background of economic deprivation and continuing charges of police brutality, the arrest of a black taxicab driver on July 12, 1967, touched off five days of explosive rioting in Newark. Rumors of police beating of the cabbie contributed to the violence. The night sky ablaze with fires, the sounds of gunfire, and the looting of mechant stores gave Newark's Central Ward the appearance of a battleground. Governor Richard J. Hughes ordered the National Guard to the city on July 14 . Black community leaders charged the predominantly white National Guard and State Police with excessive and indiscriminate use of weapons. The disorders ended on July 17 with twenty-three people dead, property damage exceeding $\$ 10,000,000$, and portions of the Central Ward in ruins. Troublesome but less serious outbreaks of looting and confrontations with the police occurred in Jersey City, Elizabeth, Englewood, and New Brunswick. Seven days after the riot in Newark was brought under control, Plainfield experienced widespread looting and sporadic violence, In Plainfield, as in Newark and other American cities, the precipitating incident involved police, but the underlying causes were the economic problems and racial discrimination facing an urbanized Afro-American population. The task of physically rebuilding the city was an important goal, but the Newark Evening News stated, "At the heart of the city's immediate problem is the reconstruction of shattered relationships between the Negro and white communities." 129

That violence erupted in the inner cities is not surprising, as urban riots, racial and nonracial, have always been a part of American history. Newark's black poet and playwright, Amiri Baraka, declared that the problems of Afro-Americans revolved around the unequal distribution of political and economic power. The decade of the 1960 s closed with blacks unified in the quest for political power. In 1967 Newark was the site of a National Conference on Black Power, and three years later, black voters were the backbone of Kenneth A. Gibson's successful campaign to become the city's first black mayor, just as in Gary, Cleveland, and other cities the growing black electorate mounted victorious mayoralty campaigns. ${ }^{130}$

\section{Recent Times}

In the 1970s the number of black elected officials increased significantly throughout the northern states and, aided by the passage of the 1965 Voting Rights Act, in the southern states as well. The municipal level had the 
greatest increases. In 1981 out of 567 New Jersey mayors, six were black. However, in a state with a 12.5 percent black population, no Afro-Americans held an office that required statewide elections such as U.S. Congressman, U.S. Senator, or Governor. Despite the rise of black political leaders, the quality of life for many of the state's black residents remained inferior to that of their white counterparts. While comprising a smaller percentage of the state's population, blacks accounted for 20 percent of the unemployment claimants, 35 percent of all infant mortality, and 49 percent of those in need of welfare assistance. ${ }^{131}$ Political advancement did not translate into rapid advancements in other areas of social and economic life.

The concentration of blacks in cities with limited financial resources and employment opportunities in part accounts for the continuing gap between the standard of living of minorities and of other residents of the state. Newark's population declined from 438,000 in 1950 to approximately 329,248 in 1980 . Much of that decline is attributable to middle-class taxpayers who sought the comforts of suburban living, weakening the tax base of the city and its ability to provide for essential services such as education, sanitation, and police protection. The creation of suburban manufacturing and service industries served by a trained middle-class work force was little help to the urban blacks most in need of employment. Although the 1975 New Jersey Supreme Court decision in the Mount Laurel case held that municipal zoning ordinances could not be used to prevent housing for low- and middle-income families, few of New Jersey's 567 municipalities have new, low-income housing. Housing opportunities for the urban poor have not materialized. The widespread abandonment and nonpayment of property taxes has further contributed to inadequate housing throughout urban America. Newark became the largest property owner as the number of foreclosures increased more than tenfold between 1965 and 1976. ${ }^{132}$ These developments have spawned a form of de facto residential segregation with concentrations of low-income minorities in the cities and middle-class whites in suburbs.

The erosion of the economic base of older American cities and the accompanying residential segregation were facilitated by some federal policies. Southern blacks continued to migrate north as the mechanization of southern agriculture reduced the need for farm workers, federal agriculture policy paid price supports for idle land, and welfare payments were inadequate for daily needs. Federal recognition of "right-to-work" laws in southern states led industries to relocate or expand into this region where unions were weaker and wages lower. This process coupled with foreign competition and the automation of American industry reduced the proportion of those unskilled positions which once had provided entrylevel manufacturing jobs. Federal policy also supported suburbanization, which drained the central city of its more affluent residents, commerce, and industry. Federal highway grants, FHA and Veterans Administration 
mortgages, and income tax benefits for homeowners made the growth of the suburbs possible. The antipoverty programs of the late 1960s and early 1970 s were too short-lived and underfunded in the era of the Vietnam War to reverse these processes. ${ }^{133}$

Progress toward racial equality has been rapid since 1945, if measured in legal and Constitutional guarantees. A growing black middle-class and significant black college population stimulate hope for the future. Yet if measured by socioeconomic standards, the disparities between minorities and whites, and even among blacks, remain too wide for comfort in a democratic society. Perhaps urban reform and revitalization movements failed because "Americans desired not a unified metropolis but a fragmented one." 134 If racial equality and harmony are to be achieved in New Jersey, they will derive from the commitment of all New Jersey's citizens to a truly democratic vision. 


\section{NOTES}

1. Clement Alexander Price, Freedom Not Far Distant: A Documentary History of AfroAmericans in New Jersey (Trenton, 1980), p. 1 (hereafter cited as FNFD); Arthur Zilversmit, The First Emancipation: The Abolition of Slavery in the North (Chicago, 1967), pp. 4-5.

2. Edgar J. McManus, Black Bondage in the North (Syracuse, N.Y., 1973), p. ix.

3. Frances D. Pingeon, Blacks in the Revolutionary Era (Trenton, 1975), pp. 5-6 (hereafter cited as BlRevEra); Price, FNFD, p. 2.

4. McManus, Black Bondage, p. 3.

5. Frances D. Pingeon, "Slavery in New Jersey on the Eve of Revolution," New Jersey in the American Revolution, ed. William C. Wright (Trenton, 1974), p. 50 (hereafter cited as "Slavery NJ"; Price, $F N F D$, p.6.

6. Pingeon, BIReoEra, p. 6; idem, "Slavery NJ," p. 51.

7. Idem, BlRevEra, pp. 6-7; Henry J. Cadbury, "Negro Membership in the Society of Friends," Journal of Negro History 21 (1936): 151-213.

8. Simeon F. Moss, "The Persistence of Slavery and Involuntary Servitude in a Free State, 1695-1866," Journal of Negro History 35 (1950): 311; Pingeon, BlRevEra, pp. 6-11; Evarts B. Greene and Virginia D. Harrington, American Population Before the Census of 1790 (Gloucester, Mass., 1932), pp. 109-112.

9. Pingeon, "Slavery NJ," pp. 51-52; Price. FNFD, p. 31.

10. McManus, Black Bondage in the North, pp. 44-45; Leonard P. Stavisky, "The Origins of Negro Craftsmanship in Colonial America," Journal of Negro History 32 (1947): 417-429.

11. Pingeon, BlRevEra, pp. 6-7.

12. The Acts of the General Assembly of the Province of New Jersey (Philadelphia, 1732), pp. 26-32; Pingeon, "Slavery NJ," p. 52.

13. Price, $F N F D$, pp. $15-16$.

14. Ibid.

15. Pingeon, "Slavery NJ," pp. 53-54; idem, BlRevEra, pp. 2, 14.

16. Idem, "Slavery NJ," pp. 55-56.

17. John Woolman, Some Considerations on the Keeping of Negroes (Philadelphia, 1754), n.p.; Zilversmit, First Emancipation, p. 66.

18. Pingeon, BlRevEra, p. 18; idem, "Slavery NJ," p. 59.

19. Gregory E. Dowd, "Declaration of Dependence: War and Inequality in Revolutionary New Jersey, 1776-1815," New Jersey History 103, nos. 1/2 (1985): 46-67.

20. Bernard Bailyn, The Ideological Origins of the American Revolution (Cambridge, Mass., 1967), pp. 232-233.

21. Pingeon, BlRevEra, p. 19; Price, FNFD, pp. 51-52.

22. Pingeon, BlReoEra, pp. 19-20.

23. Price, $F N F D$, pp. 50, 56-68.

24. Benjamin Quarles, The Negro in the American Revolution (Chapel Hill, N.C., 1961), pp. 3-18.

25. Ibid., pp. 19-32.

26. Robert J. Cough, "Black Men and the Early New Jersey Militia," New Jersey History 88 (1970): 227-230.

27. Pingeon, BlRevEra, p. 20; Price, $F N F D$, p. 53.

28. Price, FNFD, pp. 53, 63; McManus, Black Bondage, p. 158.

29. McManus, Black Bondage, pp. 123-124; Pingeon, BlRevEra, p. 21; Quarles, The Negro in the American Revolution, pp. 113-114.

30. Price, FNFD, pp. 6-71; Pingeon, BlRevEra, pp. 21-23.

31. McManus, Black Bondage, pp. 158-159; Quarles, The Negro in the American Revolution, pp. 167-172. 
32. Arthur Zilversmit, "Liberty and Property: New Jersey and the 'Self-Evident Truths,'" New Jersey in the American Revolution, Political and Social Conflicts, ed. William C. Wright (Trenton, 1974), pp. 69-71; Price, FNFD, pp. 53, 73-75.

33. Leonard B. Rosenberg, "William Paterson and Attitudes in New Jersey on Slavery," New Jersey History 95 (1970): 201, 203-204.

34. Price, FNFD, p. 53; Zilversmit, First Emancipation, pp. 192-198.

35. McManus, Black Bondage, pp. 178, 179; Zilversmit, First Emancipation, pp. 215-230; idem, "Liberty and Property," pp. 215-216; Pingeon, BIRevEra, pp. 26-27.

36. Preliminary Report of the Eighth Census, 1860. By Jos. C.G. Kennedy, Superintendent (Washington, D.C., 1860), p. 271; Peter O. Wacker, "The Changing Geography of the Black Population of New Jersey: A Preliminary View," Proceedings of the Association of American Geographers 3 (1971): 174.

37. Marion Thompson Wright, "Negro Suffrage in New Jersey, 1776-1875," Journal of Negro History 32 (1948): 177-183.

38. Price, $F N F D$, p. 88.

39. Thomas Jefferson, Notes on the State of Virginia (Chapel Hill, N.C., 1955), pp. 137142; Douglas P. Seaton, "Colonizers and Reluctant Colonists: The New Jersey Colonization Society and the Black Community, 1813-1848," New Jersey History 96 (1978): 7.

40. Seaton, "Colonizers," pp. 9-11.

41. New Jersey Colonization Society, Proceedings of a Meeting Held at Princeton (Princeton, 1824), pp. 39-40.

42. Seaton, "Colonizers," p. 12.

43. Frances D. Pingeon, "Dissenting Attitudes toward the Negro in New Jersey 1837," New Jersey History 89 (1971): 197-200.

44. Ibid., pp. 200-220.

45. Benjamin Quarles, Black Abolitionists (New York, 1969), ch. 1; Leonard I. Sweet, Black Images of America, 1784-1870 (New York, 1976), chs. 3-4.

46. Seaton, "Colonizers," pp. 13-15.

47. Samuel E. Comish and Theodore S. Wright, The Colonization Scheme Considered in Its Rejection by the Colored People (Newark, 1840), pp. 4-26.

48. Price, $F N F D$, pp. 89, 113-115.

49. McManus, Black Bondage, p. 183.

50. Wright, "Negro Suffrage," pp. 188-189; Price, FNFD, p. 91.

51. North Star, February 8, 1850; Price, FNFD, pp. 91, 119-121.

52. Walter Measdale, "Cape May and the Underground Railroad," The Cape May Magazine of History and Genealogy 7 (1975): 140-142; Price, FNFD, p. 92; William H. Siebert, The Underground Railroad from Slavery to Freedom (New York, 1899), p. 236.

53. Price, FNFD, p. 92; Siebert, Underground Railroad, pp. 174, 273.

54. William Still, The Underground Railroad (Philadelphia, 1872); Benjamin Quarles, "Foreword," to William Still, The Underground Railroad (Chicago, 1970 reprint), pp. viii-ix; William Loren Katz, "Foreword," to William Still, The Underground Railroad (New York, 1968 reprint), n. p.

55. Larry A. Greene, "The Emancipation Proclamation in New Jersey and the Paranoid Style," New Jersey History 91 (1973): 108.

56. Trenton State Gazette, September 24, 1862; Newark Daily Advertiser, September 23, 1862; West New Jersey Press, October 1, 1862; Newark Daily Mercury, September 23, 1862; Paterson Daily Guardian, October 2, 1862.

57. Trenton Daily True American. November 21, 26, 1862; Newark Daily Journal, September 23, 29, 1862; New Jersey, "Inaugural Address of Joel Parker," Legislative Documents (Trenton, 186.3), p. 13.

58. James W. Wall, Civil Liberties Overthrown in Speeches for the Times (New York, 1864), p. 61; Trenton Daily True American, March 16, 1864; Paterson Daily Register, September 24, 1862; Newark Daily Journal, September 23, 1862.

59. Greene, "Emancipation Proclamation," pp. 108-118. 
60. Price, FNFD, pp. 93, 128; William S. Stryker, Record of Officers and Men of New Jersey in the Civil War, 1861-1865, vol. 2 (Trenton, 1876), pp. 1496, 1575; William C. Wright, "New Jersey's Military Role in the Civil War Reconsidered," New Jersey History 92 (1974): 204-205. Wright claims that Stryker's estimate of 2,909 New Jersey black troops is inflated since the state had no black regiments and lost credit for black New Jerseyans entering the service in regiments of other states.

61. Kenneth Stampp, The Era of Reconstruction (New York, 1965), pp. 134-135.

62. C. Vann Woodward, Reunion and Reaction (Boston, 1951), pp. 186-246; idem, The Strange Career of Jim Crow (New York, 1966), pp. 52-79; Roger L. Ransom and Richard Sutch, One Kind of Freedom: The Economic Consequences of Fmancipation (London, 1977), pp. 1-13.

63. Marion Thompson Wright, "New Jersey Laws and the Negro," Journal of Negro History 28 (April 1943): 189; Price, FNFD, p. 131; David D. Furman, "Law and Morality Meet: The Thirteenth Amendment," in Proceedings: Fourth Annual American History Workshop presented by the New Jersey Centennial Commission (New Brunswick, 1964), pp. 60-65.

64. Daily State Gazette, Trenton, N.J., January 11, 1866, and January 18, 1871; Wright, "New Jersey Laws," p. 35; idem, "Negro Suffrage," pp. 202-204.

65. Price, $F N F D$, p. 139.

66. Samuel G. Gould, "Address Issued to the People of New Jersey by the Equal Rights League of New Jersey," Proceedings of the State Convention of Colored Men in New Jersey (Bridgeton, 1865), pp. 14-15; Wright, "Negro Suffrage," pp. 206-207.

67. Wright, "Negro Suffrage," pp. 209-210; Daily State Gazette, 'Irenton, N.J., October 21, 1866.

68. Marion Thompson Wright, The F,ducation of Negroes in New Jersey (New York, 1941), pp. 113-114, 127-130, 156.

69. Ibid., pp. $157-159$.

70. Price, $F N F D$, p. 148; Wright, "New Jersey Laws," pp. 190, 191.

71. Wright, Education of Negroes, pp. 160-161, 170-172.

72. Quoted in Price, FNFD, p. 147.

73. Ibid., p. 144; Wright, "New Jersey Laws," pp. 190-191.

74. Wright, Education of Negroes, p. 178.

75. Idem, "New Jersey Laws," pp. 178-180; W.E.B. Du Bois, The Souls of Black Folks (Chicago, 1903), pp. 15-54; New Jersey Manual Training and Industrial School for Colored Youth, Bordentown and Its Training (Bordentown, 1926), pp 3-4.

76. Price, $F N F D$, pp. 185-187. For more information on Washington and the black vocational education movement, see Louis R. Harlan, Booker T'. Washington: The Making of a Black Leader, 1856-1901 (New York, 1972).

77. Wright, "New Jersey Laws," p. 192; Price, FNFD, pp. 142-143.

78. John Hope Franklin, From Slavery to Freedom (New York, 1980), pp. 257, 266; Woodward, Jim Crow, pp. 28-50.

79. James Still, Early Recollections and Life of Dr. James Still (Philadelphia, 1877), pp. 230-240.

80. Price, $F N F D$, pp. $155-167$.

81. Ibid., pp. 167-169; Edwin S. Redkey, Black Exodus; Black Nationalist and Back to Africa Movements, 1890-1910 (New Haven, Conn., 1969), passim.

82. Richard R. Wright, "The Economic Conditions of Negroes in the North," Southern Workmen (July 1908): 385-389.

83. Ibid., pp. 390-393; Hollis R. Lynch, The Black Urban Condition (New York, 1973), pp. $23,31,32$.

84. Harlan, Booker T. Washington, pp. 311-324.

85. Henry Blumenthal, "Woodrow Wilson and the Race Question," Journal of Negro History 48 (1963): 5-7, 9-10; quoted in Oswald Garrison Villard, Fighting Years: Memoirs of a Liberal Editor (New York, 1939), p. 239. 
86. Gilbert Osofsky, Harlem, The Making of a Ghetto: Negro New York, 1890-1930 (New York, 1966), pp.46-52; William English Walling, "The Race War in the North," The Independent 65 (August 20, 1908): 529-534.

87. "The Old Story," The Crisis 1 (January 1911): 20; “The N.A.A.C.P.," The Crisis 2 (June 1911): 60.

88. Price, $F N F D$, p. 192.

89. Ibid., p. 193; New Jersey Department of Labor, Twenty-Sixth Annual Report of the Bureau of Statistics of Labor and Industries of New Jersey (Somerville, 1904), pp. 188191, 210-211.

90. Edgarton E. Hall, The Negro Wage Earner of New Jersey (New Brunswick, 1935), p. 27; Kenneth T. and Barbara B. Jackson, "The Black Experience in Newark: 'The Growth of the Ghetto, 1870-1970," in New Jersey Since 1960: New Findings and Interpretation, ed. William C. Wright (Trenton, 1972), p. 45.

91. C.F. Funnell, By The Beautiful Sea: The Rise and High Times of That Great American Resort, Atlantic City, (New York, 1975), p. 17; Department of State Census Bureau, Compendium of the Census, 1726-1905 (Trenton, 1906), pp. 3, 35; idem, State of New Jersey Census of 1915 (Union Hill, 1916), p. 53.

92. Herbert J. Foster, "Institutional Development in the Black Community of Atlantic City, New Jersey: 1860-1930," The Black Experience in Southern New Jersey: Papers Presented at the Camden Historical Society (Camden, 1985), pp. 33-42.

93. Price, $F N F D$, p. 195; idem, "The Beleaguered City as Promised Land: Blacks in Newark, 1917-1947," in Urban New Jersey Since 1870, ed. William C. Wright (Trenton, 1975), pp. 14-15, 39.

94. Jackson, "Black Experience," pp. 53-54; Price, "Beleaguered City," pp. 23-24; Beatrice A. Myers and Ira DeA. Reid, "The Toll of 'Tuberculosis Among Negroes in New Jersey," Opportunity 10 (1932): 279-282; Helen B. Pendleton, "Cotton Pickers in Northern Counties," Survey 34 (February 17, 1917): 569-571.

95. Spencer R. Crew, "Making Their Own Way: Black Social and Institutional Life in Camden, New Jersey, 1860-1920," Black Experience in Southern New Jersey, pp. 1929; Foster, "Institutional Development," pp. 15, 18, 21; Jackson, "Black Experience," pp. 55-56; Price, FNFD, p. 197.

96. George Fishman, "Paul Robeson's Student Days and the Fight against Racism at Rutgers," Freedomways 9 (1969): 223-225.

97. Bernard C. Nalty, Strength for the Fight: A History of Black Americans in the Military (New York, 1986), p. 132; Edward Wakin, Black Fighting Men in U.S. History (New York, 1971), pp. 100-102; Gerald W. Patton, War and Race: The Black Officer in the American Military, 1914-1941 (Westport, Conn., 1981), p. 134.

98. Howard B. Furer, "The Perth Amboy Riots of 1923," New Jersey History 87 (1969): 211-232.

99. State of New Jersey Emergency Relief Administration, Unemployment and Relief Conditions in New Jersey (Trenton, 1932), p. 13; idem, Third Annual Report (Trenton, 1934); Interracial Committee of the New Jersey Conference of Social Work, The Negro in New Jersey (New York, 1932, reprint 1969), p. 30.

100. Quoted in Jackson, "Black Experience," pp. 49-50; Price, FNFD, p. 198.

101. New Jersey Urban Colored Population Experience, Annual Report: 1943 (Newark, 1943), n.p.; Price, "Beleaguered City," p. 32; Jackson, "Black Experience," p. 49; State of New Jersey Emergency Relief Administration, Negroes on the Road: A Study of Transient Negroes in New Jersey (Trenton, 1934), p. 1.

102. Myers and Reid, "Toll of Tuberculosis," pp. 279-282; N.J. Conference of Social Work, The Negro in New Jersey, pp. 37, 48, 62-64, 99.

103. Price, $F N F D$, p. 225.

104. Ibid., p. 199.

105. New Jersey Herald Newes, August 20, 1938. 
106. Idem, February 25, 1939; Andrew Buni, Robert L. Vann of the Pittshurgh Courier; Politics of Black Journalism (Pittsburgh, 1974), p. 325; Herbert Garfinkle, When Negroes March (New York, 1969), pp. 60-64.

107. New Jersey Herald News, January 14, 20, and February 27, 1943; Richard M. Dalfiume, "The 'Forgotten Years' of the Negro Revolution," Journal of American History 55 (June 1968): 90-106; State of New Jersey, Urban Colored Population Commission, The New Jersey Negro in World War II ('Trenton, 1945), n.p.

108. Ibid, n.p.

109. Richard M. Dalfiume, Desegregation of the U.S. Armed Forces: Fighting on Two Fronts, 1939-1945 (Columbia, Mo., 1969), pp. 105-131.

110. Barton J. Bernstein, "The Ambiguous I egacy: 'I'he Truman Administration and Civil Rights," Politics and Policies of the Truman Administration, ed. Barton J. Bernstein (Chicago, 1978), pp. 277-280, 297-298; Franklin, From Slavery to F reedom, pp. 450-451.

111. Richard Kluger, Simple Justice: The History of Brown v. Board of Education and Black America's Struggle for F.quality (New York, 1976), p. 562; Franklin, From Slavery to Freedom, pp. 453-454.

112. August Meier and Elliott Rudwick, CORE: A Study in the Civil Rights Movement: 1942-1968 (New York, 1973), pp. 75-76, 101-373.

113. Price, $F N F D$, p. 258.

114. George Chester Morse, "New Jersey, New Laboratory in Race Relations," Negro History Bulletin 113 (April 1950): 158; Price, FNFD, p. 247.

115. Clifford F. Moore, "Full Citizenship in New Jersey," The Crisis 56 (October 1949), pp. 272, 284; New Jersey State Conference of NAACP Branches, "A Survey of the Public School Systems in the State of New Jersey" (New York, February 28, 1947), pp. 1-6.

116. State of New Jersey, Constitutional Convention of 1947, vol. 3, Committee on Rights, Privileges, Amendments and Miscellaneous Provisions (Trenton, 1947), pp. 89-96; ibid., "Resolution of the New Jersey State Federation of Colored Women's Clubs," pp. 421-422; Moore, "Full Citizenship," p. 273.

117. Moore, “Full Citizenship," pp. 272-273; Price, FNFD, pp. 250, 270.

118. Morse, "New Jersey, New Laboratory," p. 159; Moore, "Full Citizenship," p. 273.

119. Marion Thompson Wright, "Extending Civil Rights in New Jersey Through the Division Against Discrimination," Journal of Negro History 38 (January 1953), pp. 98, $100,103,105$.

120. Price, $F N F D$, p. 247

121. Ibid., p. 278; Elwood M. Dean, The Story of the Trenton Six (New York, 1949), passim; NAACP, Legal Defense and Educational Fund, Inc., The Fantastic Case of the Trenton Six (New York, 1951), passim; Bruce Bliven, "Who Believed in Justice," New Republic 12.5 (October 1951), pp. 13-15; Morse, "New Jersey, New Laboratory," p. 161.

122. Price, $F N F D$, p. 252.

123. Robert Curvin, "Black Ghetto Politics in Newark After World War II," Cities of the Garden State: Essays in the Urban and Suburban History of New Jersey, ed. Joel Schwartz and Daniel Prosser (Dubuque, 1977), pp. 146-148.

124. Ibid., pp. $150-154$.

125. Ibid., pp. 154-156.

126. Price, FNFD, p. 253.

127. U.S. Riot Commission, Report of the National Advisory Commission on Civil Disorders (Washington, D.C., 1968), pp. 13, 14, 132.

128. Ibid., pp. $59,69$.

129. Ibid., pp. 60-69, 70-83; Newark Evening News, July 18, 1967; New Jersey Governor's Select Commission on Civil Disorder, Report for Action (Trenton, 1968), pp. 104144.

130. Price, FNFD, pp. 254, 257. 
131. New Jersey Public Policy Research Institute, Blacks in New Jersey - 1982, Third Annual Report (Piscataway, 1982), pp. 9, 10.

132. Stanley B. Winters, "Introduction, Turbulent Decade: Newark Since the Riots," Newark: An Assessment, 1967-1977, ed. Stanley B. Winters (Newark, 1978), pp. 3, 8; Price, FNFD, p. 302; State of New Jersey Department of Labor, New Jersey 1980 Census of Population and Housing, Municipal Profiles; Volume I: Characteristics of Persons (Trenton, January 1982), n.p.

133. Frances Fox Piven, "The Shaping of Our Newarks," Newark, An Assessment, pp. 29_ 33; Jay R. Mandle, The Roots of Black Poverty: The Southern Plantation Economy After the Civil War (Durham, N.C., 1978), pp. 84-104.

134. Jon C. Teaford, The Twentieth-Century American City: Problem, Promise, and Reality (Baltimore, 1986), p. 186.

Bibilographical Essay

There are many valuable sources for the study of Afro-American history in New Jersey. Giles R. Wright, Afro-Americans in New Jersey: A Short History, is an excellent general treatment. Marion Thompson Wright's The Education of Negroes in New Jersey (New York, 1941) is a pioneer work surveying the black experience in the state from colonial times through the early twentieth century. An invaluable collection of documents and commentary for the study of New Jersey blacks is Clement Alexander Price's Freedom Not Far Distant: A Documentary History of Afro-Americans in New Jersey (Trenton, 1980). A brief overview of New Jersey black history is Lee Hagan, Larry A. Greene, Leonard Harris, and Clement A. Price, "New Jersey Afro-Americans: From Colonial Times to the Present," in The New Jersey Ethnic Experience, ed. Barbara Cunningham (Union City, N.J., 1977). An excellent bibliographical guide to primary and secondary sources is New Jersey and the Negro: A Bibliography, 1715-1966 (Trenton, 1967). Readers will find most useful a general bibliography, The Negro in America (Cambridge, Mass., 1970) compiled by Mary L. Fisher. The endnotes of each chapter of this work provide a more complete guide to sources consulted for this study.

Slavery in New Jersey, like Afro-American history in general, has been given the most attention by researchers. Henry Schofield Cooley's A Study of Slavery in New Jersey (Baltimore, 1896) remains an important work, especially for the legal system and slavery. Another important older work is Hubert G. Schmidt's "Slavery and Attitudes on Slavery in Hunterdon County, New Jersey," Proceedings of the New Jersey Historical Society 58 (1940). Other thoroughly researched studies of early New Jersey slavery and the impact of the American Revolution are Frances D. Pingeon, Blacks in the Revolutionary Era (Trenton, 1975) and her "Slavery in New Jersey on the Eve of Revolution," in New Jersey in the American Revolution: Political and Social Conflict, ed. William C. Wright (Trenton, 1974). Pingeon also wrote on the subject: "An Abominable Business: The New Jersey Slave Trade," New Jersey History, (Fall/Winter 1991), v. 109 (nos. 3 \& 4), pp. 15-35. Two readable and detailed accounts of slavery and emancipation in the northern states which cover New Jersey are Arthur Zilversmit, The First Emancipation: 
The Abolition of Slavery in the North (Chicago, 1967) and Edgar J. McManus, Black Bondage in the North (Syracuse, 1973). Marion Thompson Wright explored the relationship between race and civil rights in "Negro Suffrage in New Jersey, 1776-1875." Journal of Negro History 33 (1948) and "New Jersey Laws and the Negro," Journal of Negro History 28(1943). New Jersey attitudes toward colonization are analyzed in Robert J. Williams, "Blacks, Colonization, and Antislavery: The Views of Methodists in New Jersey, 1816-60," New Jersey History 102(1984) and Douglas P. Seaton's “Colonizers and Reluctant Colonists: The New Jersey Colonization Society and the Black Community, 1815-1848," New Jersey History 96 (1978).

The settlement patterns of New Jersey's black population have been studied by Peter O. Wacker in "The Changing Geography of the Black Population of New Jersey, 1810-1860: A Preliminary View," Proceedings of the Association of American Geographers 3 (1971). For the origins of free black towns, see William Steward, Gouldtown (Philadelphia, 1913) and Charles C. Smiley, A True Story of Lawnside, N.J. (Camden, 1921). David S. Cohen studied the mulatto settlements in the Ramapo mountains in The Ramapo Mountain People (New Brunswick, 1974).

Racial attitudes during the Civil War era have been studied in a number of articles. Carl E. Hatch has explored antiblack thought and opposition to black migration to the state in "Editor David Naar of Trenton: Profile of the Anti-Negro Mind," New Jersey History 86 (1968) and "Negro Migration and New Jersey-1863," New Jersey History 87 (1969). Frances D. Pingeon examined racial perceptions in "Dissenting Attitudes toward the Negro in New Jersey-1837," New Jersey History 89 (1971). Lee Calligaro reviewed New Jersey's race laws in "The Negro's Legal Status in Pre-Civil War New Jersey," New Jersey History 85 (1967). Larry A. Greene's "The Emancipation Proclamation in New Jersey and the Paranoid Style," New Jersey History 91 (1973) analyzes the state's reaction to southern emancipation. The New Jersey Civil War Centennial Commission held a conference which included papers on New Jersey in the Civil War and the reaction to the freedom amendments, published in Proceedings, Fourth Annual American History Workshop (New Brunswick, 1964).

Dissertation studies of Afro-American history in New Jersey in the twentieth century focusing on blacks in large urban communities include Clement Alexander Price, "The Afro-American Community of Newark, 1917-1947: A Social History," (Ph.D. diss., Rutgers University, 1975); Robert Curvin, "The Persistent Minority: The Black Political Experience in Newark," (Ph.D. diss., Princeton University, 1975); Herbert J. Foster, "The Urban Experience of Blacks in Atlantic City, New Jersey: 1850-1915" (Ph.D. diss., Rutgers University, 1981); and Spencer R. Crew, "Black Life in Secondary Cities: A Comparative Analysis of the Black Communities of Camden and Elizabeth, New Jersey: 1860-1920" (Ph.D. diss., Rutgers University, 1979). Black migration and community formation is covered in 
a survey of Newark by Kenneth T. and Barbara B. Jackson, "The Black Experience in Newark: The Growth of the Ghetto, 1870-1970," in New Jersey Since 1860, Newe Findings and Interpretations, ed. William C. Wright (Trenton, 1972) and in Clement Alexander Price, "The Beleaguered City as Promised Land: Blacks in Newark, 1917-1947," in Urban New Jersey Since 1870, ed. William C. Wright (Trenton, 1975). Three studies of twentiethcentury black protest against discrimination and segregation are: August Meier and Elliott M. Rudwick, "Early Boycotts of Segregated Schools: The East Orange, New Jersey, Experience, 1899-1906," History of Education Quarterly 7 (1967); Clement A. Price, "The Struggle to Desegregate Newark: Black Middle Class Militancy in New Jersey, 1932-1947." Newe Jersey History 99 (1981); and Michael H. Ebner, "Mrs. Miller and 'The Paterson Show': A 1911 Defeat for Racial Discrimination," New Jersey History 86 (1968).

The status of blacks during the Depression and World War II is covered in articles in Crisis and Opportunity, the official organs of the NAACP and the Urban League, respectively. Studies by the WPA-sponsored Federal Writers Project contain valuable data for the 1930s. The State of New Jersey's Report of the New Jersey State Temporary Commission on the Condition of the Urban Colored Population (Trenton, 1939) also contains useful data on blacks in various cities. The Interracial Committee of the New Jersey Conference of Social Work's The Negro in New Jersey (Newark, 1932) is most informative.

Civil rights and black politics in the post-World War II era are treated in Robert Curvin's "Black Ghetto Politics in Newark after World War II," in Cities of the Garden State: Essays in Urban and Suburban History of New Jersey, Joel Schwartz and Daniel Prosser (Dubuque, Iowa, 1977). Marion Thompson Wright discusses early civil rights legislation and enforcement in "Extending Civil Rights in New Jersey through the Division against Discrimination," Journal of Negro History 38 (1953).

Urban disorders in the 1960 s are examined on a national scale in the Report of the National Advisory Commission on Givil Disorders (New York, 1968 ) and within the state in the Governor's Select Commission on Civil Disorder, Report for Action (Trenton, 1968). Ron Porambo's No Cause for Indictment: An Autopsy of Newark (New York, 1971) provides a thorough description of the Newark riot of 1967. Another analysis of the Newark riot is Daniel E. Georges, "Arson: The Ecology of Urban Unrest in an American City" (Ph.D. diss., Syracuse University, 1974). Ten years after the riot, scholars and civic leaders reflected on Newark's past and future in Newark: A $n$ Assessment, 1967-1977, ed. Stanley B. Winters (Newark, 1978).

Black newspapers like the New Jersey Herald, Sentinel, and New Jersey 4 froAmerican are available at the Alexander Library of Rutgers University and the Schomburg Center of the New York Public Library. Oral history is a particularly valuable tool for those studying twentieth-century black history. Ronald J. Grele's Oral History in New Jersey: A Directory, 1979 (Trenton, 1979 ) is an excellent guide to collections in the state. 
Further readings of interest in New Jersey History include: Spencer R. Crew, "Black New Jersey before the Civil War: Two Case Studies," 99 (1981): 66-86; John Cudd, "The Unity of Reform: John Grimes and the Nerw Jersey Freeman," 97 (1979): 197-212; Joseph S. Darden and Dennis C. Dickerson, "Dr. Walter G. Alexander and Black Education: Comment and Response," 105, nos. 3/4 (1987): 70-79; Dennis C. Dickerson, "Walter G. Alexander: a Physician in Civil Rights and Public Service," 101, nos. 3/4 (1983): 36-59; Gregory E. Dowd, "Declaration of Dependence: War and Inequality in Revolutionary New Jersey, 1776-1815," 103, nos. 1/2 (1985): 46-47; Robert J. Gough, "Black Men and the Early New Jersey Militia," 88 (1970): 227-238; Patricia Jones Gregory, "Elizabeth Catlett: A Paradigm of Collective Consciousness in African American Art: A Multi-Cultural Curriculum Resource" (Ed.D. dissertation, Seton Hall University, 1994); Leonard B. Rosenberg, "William Paterson and Attitudes in New Jersey on Slavery," 95 (1977): 197-206; and Marion Thompson Wright, "Mr. Baxter's School," 59 (1941): 116-133. 